\title{
New reflections on the structure and evolution of the Makkovikian - Ketilidian Orogen in Labrador and southern Greenland
}

\author{
Andrew Kerr ${ }^{1}$ \\ Geological Survey, Newfoundland Department of Mines and Energy, St. John's, Newfoundland, Canada \\ Jeremy Hall \\ Department of Earth Sciences, Memorial University of Newfoundland, St. John's, Newfoundland, Canada \\ Richard J. Wardle, Charles F. Gower, and Bruce Ryan \\ Geological Survey, Newfoundland Department of Mines and Energy, St. John's, Newfoundland, Canada
}

\begin{abstract}
Marine seismic reflection profiles across the Early Proterozoic Makkovikian - Ketilidian Orogen in the Labrador Sea region suggest that it is a doubly vergent, asymmetric orogenic belt, comparable in width to younger collisional orogens. A southeast dipping reflector package is correlated with on-land shear zones that mark the southeastern limit of exposed reworked Archean crust and is also associated with a cryptic isotopic boundary in granites, which documents a transition from "ancient" to "juvenile" basement. This boundary is interpreted as a suture, along which juvenile Proterozoic crust has been juxtaposed over (thrust over ?) the Archean craton. A major synorogenic to postorogenic plutonic terrane to the southeast has a poorly reflective upper crust but shows strong subhorizontal reflectivity in the lower crust and Moho regions. The southeastern part of the profile correlates with metasedimentary terranes of the Ketilidian Belt in Greenland and contains low-angle, northwest dipping, reflector packages suggestive of large-scale crustal imbrication by thrusting. At least two broad zones of reflectivity at mantle depths (up to $16 \mathrm{~s}$ ) are also recognized. One dips northwest below the Archean craton, but the most widespread mantle reflectivity is southeast dipping in opposition to the dominant fabric in the overlying crust. These contrasting crustal and subcrustal reflectivity patterns define a geometric "focus" beneath the orogenic belt and may provide information about subduction polarity during its development. The doubly vergent reflectivity pattern resembles images from possibly correlative Precambrian orogenic belts such as the Penokean and Svecofennian and also younger "small collisional orogens" such as the Appalachian and Pyrenean belts. It also broadly resembles some results of geodynamic crustal deformation models based on detachment and underthrusting of mantle lithosphere following collision and the squeezing of
\end{abstract}

Department of Earth Sciences, Memorial University of Newfoundland, St. John's, Newfoundland, Canada.

Copyright 1997 by the American Geophysical Union.

Paper number 97TCO2286.

0278-7407/97/97TC-02286\$12.00 "weak" zones between rigid bounding blocks. A speculative multistage model for the belt incorporates initial northward subduction beneath the craton, shifting to later southward subduction, followed by oblique accretion of a composite arc terrane and juvenile (?) continental block. The accreted, hotter, juvenile, Proterozoic crust behaved differently than the stable, cool, Archean crust and experienced subhorizontal shearing in lower crustal and Moho regions, associated with southeast directed imbrication of the middle and upper crust by thrusting. However, the present reflectivity pattern of the orogen may also include elements related to post collisional extensional collapse.

\section{Introduction}

Reflection seismology assists in understanding crustal anatomy by providing vertical sections that augment the largely two-dimensional plan view afforded by bedrock geology. Profiles acquired under the Canadian Lithoprobe project provide important constraints for multidisciplinary modeling of the tectonic evolution of orogenic belts in North America. The Lithoprobe Eastem Canadian Shield Onshore - Offshore Transect (ECSOOT) is directed toward the Precambrian crust of Labrador and adjacent Quebec (Figure 1), where approximately $1250 \mathrm{~km}$ of marine seismic reflection profiles were acquired in 1992. Technical data, acquisition parameters, processed seismic sections, and initial interpretations of large-scale crustal anatomy are presented elsewhere [Hall et al., 1995].

This paper is a more detailed examination of part of the ECSOOT profile across the southern North Atlantic Craton and Proterozoic orogenic belts that bound it to the south (Figure 1). It focuses on a - 400-km cross section of the Makkovikian Orogen, an Early Proterozoic (2.1 to $1.7 \mathrm{Ga}$ ) mobile belt, which was contiguous with the Ketilidian Orogen of southwest Greenland prior to Mesozoic opening of the Labrador Sea (Figures 1 and 2). The seismic reflection data permit assessment and development of plate-tectonic models for this belt and for Proterozoic orogens in general. An associated paper [Gower et al., 1997] discusses the adjoining 


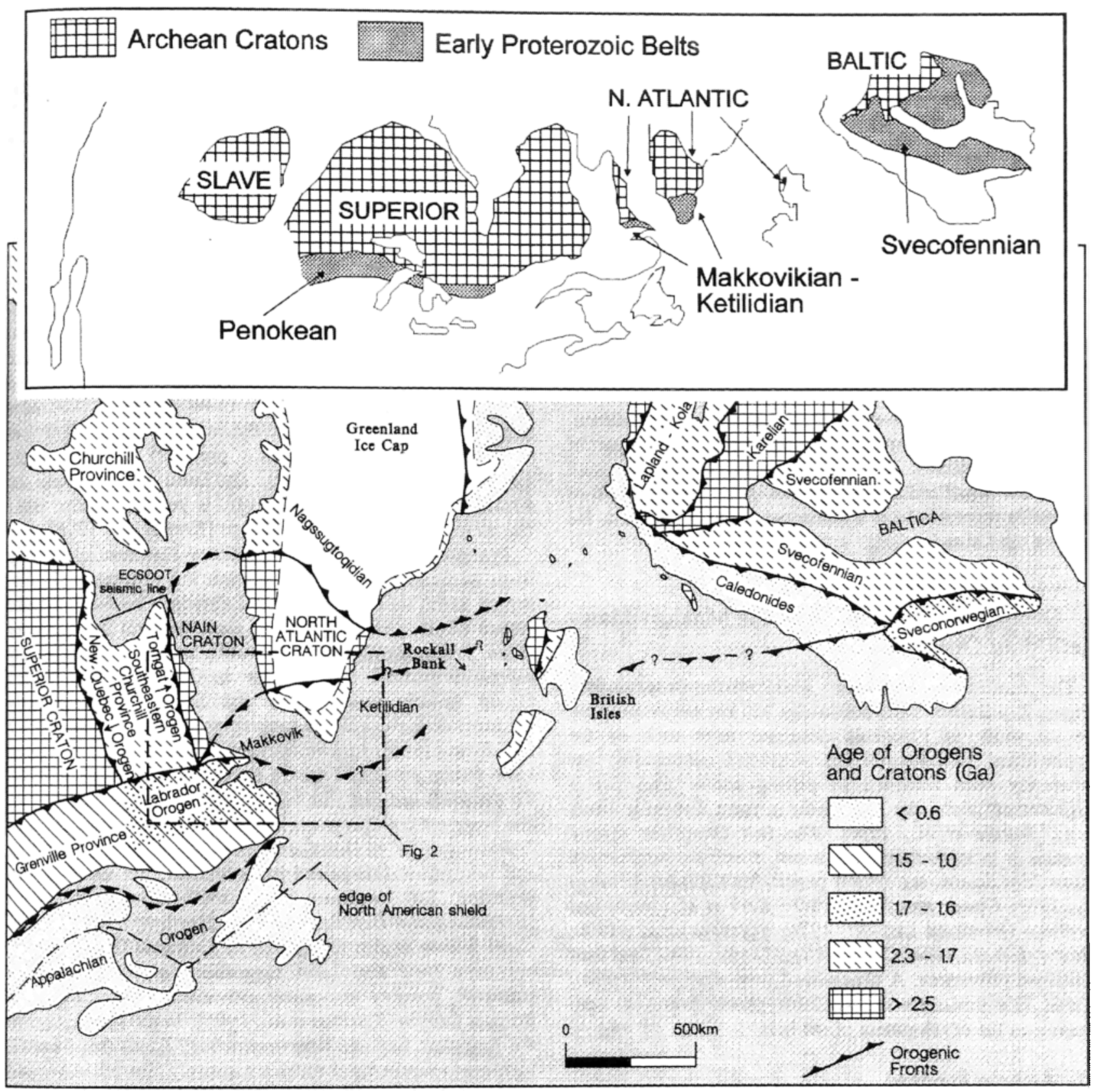

Figure 1. Tectonic provinces and orogenic belts of the North Atlantic region in mid-Proterozoic times [after Gower et al., 1990], showing locations of Makkovikian - Ketilidian Orogen and the Lithoprobe Eastern Canadian Shield Onshore-Offshore Transect (ECSOOT) seismic reflection profiles. Inset map shows the locations of potentially correlative belts along the reconstructed southern margin of Laurentia - Baltica.

portion of the ECSOOT profile across the Early and Middle Proterozoic Labradorian and Grenvillian orogenic belts (Figures 1 and 2).

\section{Regional Setting and Pre-Mesozoic Plate Reconstruction}

The Makkovikian - Ketilidian orogenic belt is located between the Archean North Atlantic Craton (termed Nain Province in Labrador) and the Grenville Province (Figure 1).
Labrador - Greenland correlations have been extensively discussed [e.g., Kranck, 1939; Sutton et al., 1972; Bridgwater et al., 1973; Gower and Ryan, 1986; Kerr et al., 1996], and the former continuity of the two Precambrian shields is widely accepted. On a larger scale, the Makkovikian and Ketilidian Orogens are parts of an extensive belt of Proterozoic crust on the southern margin of Laurentia - Baltica (Figure 1), probably including the Penokean of central North America and the Svecofennian of Scandinavia [Gower et al., 1990]. 
The bathymetric fit of Bullard et al. [1965] was the first pre-Mesozoic reconstruction of the Labrador Sea area and has been widely used in continental reconstructions. This paper uses a reconstruction (Figure 2) that is specific to the Labrador Sea, which shifts Greenland southward by approximately $100 \mathrm{~km}$ [Srivastava and Roest, 1989; Roest and Srivastava, 1989]. Note that the fit does not account for any stretching associated with rifting, which may have increased the widths of outer shelf regions by up to $50 \%$ [Srivastava and Verhoef, 1992]. Stretching may be an important factor, as the reconstructed continental shelves reveal an axial positive gravity anomaly up to $150 \mathrm{~km}$ wide [Srivastava and Roest, 1989] (Figure 3b), which may in part represent crustal extension. However, the seismic reflection profile is located landward of the axial positive gravity anomaly, except near $\mathrm{km} 400$ (Figure $3 \mathrm{~b}$ ) and thus provides images of crust that should not have been strongly affected by Mesozoic extension. Sedimentary cover is thin (generally $<1 \mathrm{~km}$ ) in the northern part of the profile but thickens to around $3 \mathrm{~km}$ near the turning point at $\mathrm{km} \mathrm{430}$. Small sedimentary basins in the northern part of the profile represent local extensional features related to the birth of the Labrador Sea.

\section{Geological Framework of the Makkovikian - Ketilidian Orogenic Belt}

The reconstructed Ketilidian - Makkovikian Orogenic Belt (Figure 2) measures some $600 \mathrm{~km}$ by $350 \mathrm{~km}$ and is comparable in width to Paleozoic orogenic belts such as the Applachians. In Labrador, its westward continuation has apparently been removed by rifting and/or transcurrent displacement along the line of the present Grenville Front [e.g., Wardle et al., 1990]. The belt comprises several domains or tectonostratigraphic zones, which are summarized below. For details, see review papers for Labrador [Ryan et al., 1983; Gower and Ryan, 1986; Kerr et al., 1996] and southern Greenland [Allaart, 1976; Kalsbeek et al., 1990; Chadwick et al., 1994; Chadwick and Garde, 1996], and their contained references. A generalized time-stratigraphic chart (Table 1) summarizes the available geochronological constraints on the development of the belt.

\subsection{Archean Foreland}

Archean crust of the North Atlantic Craton forms the foreland to the belt (Figures 1 and 2). In Labrador, Archean gneisses of the northern Nain Province resemble those of west Greenland [e.g., Bridgwater and Schiette, 1990] and date back to $\sim 3.9 \mathrm{Ga}$; however, the southern part of the craton mostly formed $\sim 3.2$ to $2.8 \mathrm{Ga}$ ago [e.g., Loveridge et al., 1987; Kalsbeek et al., 1990]. The Archean craton consists of grey tonalitic to granodioritic gneisses, with early supracrustal remnants, and small greenstone belts (Florence Lake and Hunt River belts in Labrador and Tartoq Group in Greenland). On both sides of the Labrador Sea, Early Proterozoic dyke swarms (2.23-Ga Kikkertavak dykes in Labrador and undated Iggavik dykes in Greenland) constrain Proterozoic deformation because they are folded, attenuated, and metamorphosed in reworked areas (see below).

\subsection{Kaipokok Domain (Labrador) - Border Zone (Greenland)}

This section of the orogenic belt (Figure 2) consists largely of reworked Archean gneisses. The "reworking front" is a 2$\mathrm{km}$-wide vertical mylonite zone in Labrador (Kanairiktok Shear Zone), juxtaposing greenschist and amphibolite Proterozoic metamorphic facies. The 2.23-Ga Kikkertavak dykes are undeformed to the north but are strongly attenuated and deformed to the south [Ryan et al., 1983]. There is no well-defined "front" in Greenland, where metamorphism and deformation instead increase over a distance of some $75 \mathrm{~km}$ [Berthelsen and Henriksen, 1975]. As in Labrador, Proterozoic mafic dykes record a progressive increase in structural reworking toward the south. These differences suggest a more gradual transition in the Proterozoic crustal level in Greenland compared to Labrador. Recent U-Pb dating in Labrador indicates metamorphism of the dykes at $1.9 \mathrm{Ma}$ [Ketchum et al., 1995], consistent with the pre-1895 Ma reworking inferred by Kerr et al. [1992]. The latest activity along the Kanairiktok Shear Zone, however, is younger than $\sim 1.81$ $\mathrm{Ga}$, as it affects granites of that age [Kerr et al., 1996].

Proterozoic supracrustal sequences rest unconformably upon Archean crust in the north but are progressively disrupted to the south and east. In Labrador, the Moran Lake Group [Ryan, 1984] comprises shallow-water sedimentary rocks, passing upward into greywacke and shale, overlain by submarine mafic volcanic rocks. In Greenland, the Vallen Group (mostly sedimentary) and Sortis Group (mostly volcanic) define a similar stratigraphy [Allaart, 1976; Gower and Ryan, 1986]. In Labrador, deformation of the Moran Lake Group predates $1.89 \mathrm{Ga}$ granites [Kerr et al., 1992]. To the south and east, the basal unconformity is obliterated, and basement-cover contacts become mylonitic zones (termed "gneissic schists" in Greenland). Northwest directed thrusting and folding are recognized in Greenland, but there is also evidence for westward and southeastward transport [Berthelsen and Henriksen, 1975]. Northwest verging isoclinal folding is also recognized in Labrador [Ryan, 1984], but there have also been suggestions of early eastward transport, possibly associated with events in the adjoining Tomgat Orogen [Ketchum et al., 1995]. In the south, near to the Kaipokok Bay and Kobberminebugt Zones (see below), high-grade supracrustal rocks are entirely allochthonous and are rotated into parallelism with "straightened" (i.e., transposed), mylonitized, gneisses and dyke remnants [Ryan et al., 1983; Allaart, 1976].

Proterozoic plutonic suites are present in both areas. In Labrador, the Island Harbour Bay plutonic suite includes early (undated) tonalitic-trondhjemitic rocks and younger fluorite-bearing granites dated at $1.8 \mathrm{Ga}$ [Loveridge et al., 1987; Ermanovics, 1992]. In Greenland, "early" (foliated) and late (unfoliated) granites cut the gneisses [Kalsbeek et al., 1990]. Potassic granites in the Kaipokok Domain, dated at 1.89 to $1.87 \mathrm{Ga}$ [Kerr et al., 1992; Ketchum et al., 1995] are older than most other Makkovikian and Ketilidian plutonic rocks (see below); similar ages were obtained from offshore wells ELS-62 and ELS-90 (Figure 2) [Wasteneys et al., 1992]. Field evidence in Labrador indicates that granite emplacement and migmatization(s) preceded interleaving of 


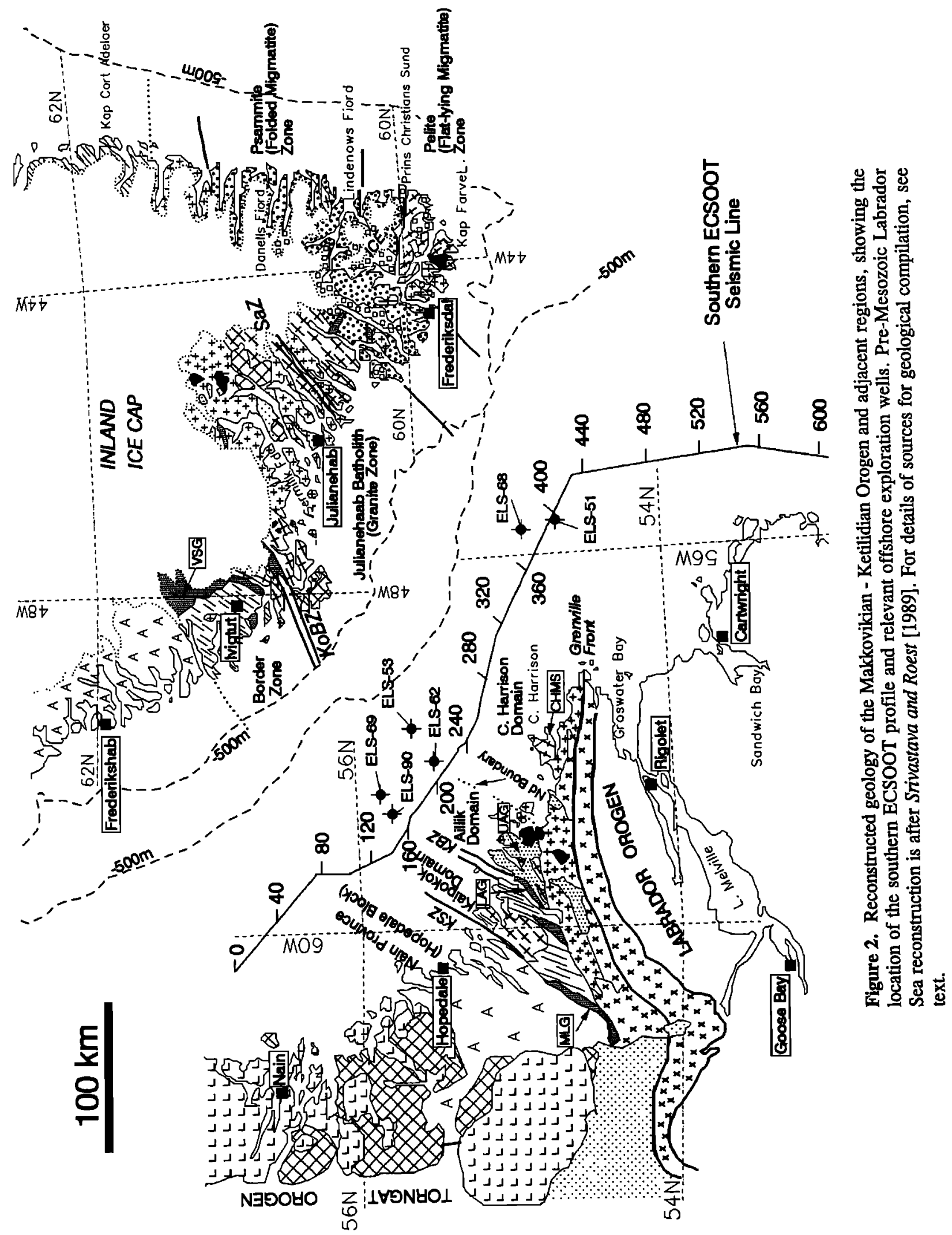




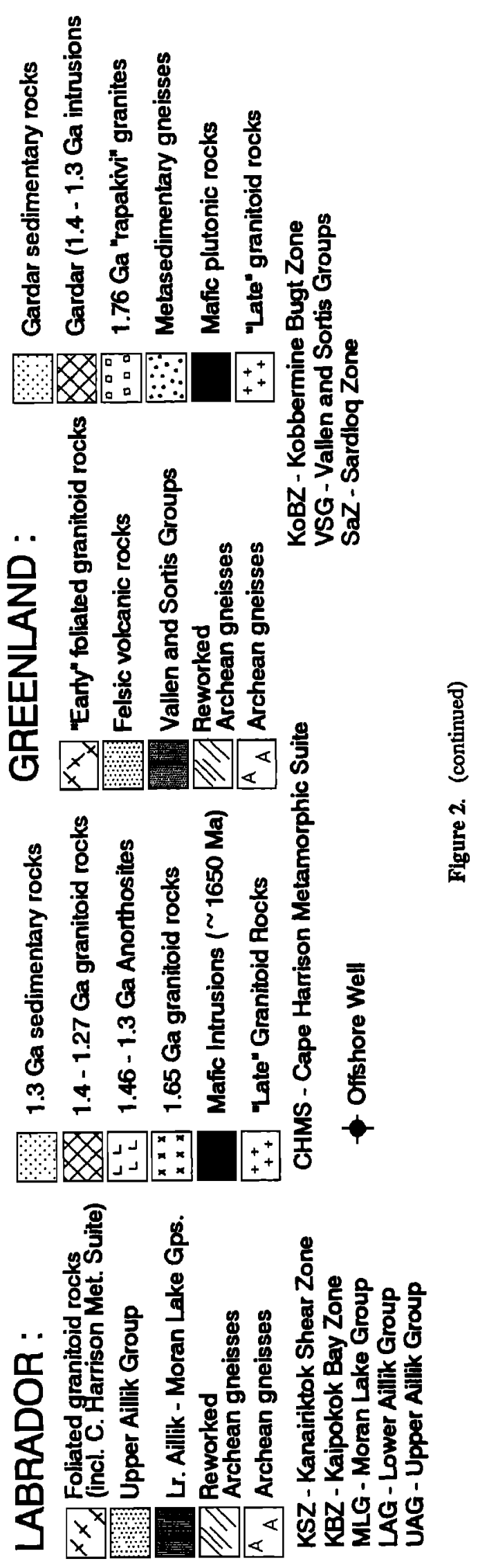

Archean basement and Proterozoic cover (Iggiuk Event [Ryan et al., 1983; Schärer et al., 1988]), indicating an unresolved early thermal history throughout this region. Although details are scanty, it seems clear that the northwestem margin of the orogenic belt, at least in Labrador, has a complex early tectonic history. Detailed geochronological data are lacking from equivalent regions in Greenland.

3.3. Kaipokok Bay Zone (Labrador) - Kobberminebugt Zone (Greenland)

On both sides of the Labrador Sea, the reworked Archean region is separated from the internides of the orogen by a major discontinuity. In Labrador, the Kaipokok Bay Zone is a zone of intense ductile deformation, where supracrustal rocks (Lower Aillik Group) are juxtaposed against reworked Archean gneisses across kilometer-scale mylonite zones. The Lower Aillik Group is considered to be a high-grade equivalent of the Moran Lake Group [Wardle and Bailey, 1981]. The shear zones are subvertical, but some probably originated as thrusts, although kinematic indicators are largely overprinted by pervasive late dextral deformation [Ryan et al., 1983; Culshaw and Ketchum, 1994]. Foliated to gneissic granites (locally recording anatexis) within the zone are dated at $\sim 1.8 \mathrm{Ga}$. U-Pb titanite ages of $1.76-1.74 \mathrm{Ga}$ suggest a long history of thermal activity [Kerr et al., 1992; Ketchum et al., 1996]. In Greenland, the Kobberminebugt Zone is a $15-\mathrm{km}$-wide subvertical to steeply south dipping zone of ductile deformation including high-grade supracrustal rocks, gneisses, and deformed (locally anatectic) granites, with subborizontal lineations suggesting transcurrent motion. As in Labrador, the sense of earlier motions and original attitudes of structures are difficult to establish.

\subsection{Aillik Domain (Labrador)}

In Labrador, a 20-km-wide zone southeast of the Kaipokok Bay Zone is dominated by sedimentary rocks and 1.86 and $1.81 \mathrm{Ga}$ felsic volcanic rocks of the Upper Aillik Group [Gower and Ryan, 1987; Schärer et al., 1988]. The latter have potassic, high-SiO ${ }_{2}$ compositions and local alkaline tendencies. The stratigraphic relationship between the Lower and Upper Aillik Groups is unknown, as their contact is a zone of intense deformation. Felsic volcanic rocks are less abundant in Greenland, but metasedimentary and intermediate volcanic rocks of the Ilordleq Group [Allaart, 1976; Kalsbeek et al., 1990] occupy an equivalent spatial location. These are generally considered to overlie the high-grade supracrustal rocks of the Kobberminebugt Zone, but, as in Labrador, the relationship is equivocal. Intermediate and felsic volcanic rocks also occur in inland areas (Figure 2) associated with plutonic rocks [Allaart, 1976; Kalsbeek et al., 1990].

Syntectonic and posttectonic plutonic rocks of $1.80,1.72$, and $1.65 \mathrm{Ga}$ age also occur as scattered plutons within the Aillik Domain; the older examples were likely comagmatic with younger parts of the Upper Aillik Group [Gower and Ryan, 1987; Kerr et al., 1992].

\subsection{Cape Harrison Domain (Labrador) - Julianehảb Batholith (Greenland)}

The Cape Harrison Domain in Labrador is dominated by plutonic suites and is equivalent to the "Granite Zone" 
Table 1. A Summary Time-Stratigraphic Chart for the Makkovikian - Ketilidian Orogen in Labrador and Southern Greenland

\begin{tabular}{|c|c|c|c|c|c|}
\hline \multicolumn{6}{|c|}{ Makkovik Province of Labrador } \\
\hline & Kaipokok Domain & & Aillik Domain & & Cape Harrison Domain \\
\hline \multirow[t]{2}{*}{$1.65 \mathrm{Ga}$} & Minor mafic plutonic rocks & $1.65 \mathrm{Ga}$ & $\begin{array}{l}\text { minor mafic and granitic } \\
\text { plutonic rocks }\end{array}$ & $1.65 \mathrm{Ga}$ & $\begin{array}{l}\text { emplacement of layered } \\
\text { gabbro-monzonite- } \\
\text { syenite intrusions }\end{array}$ \\
\hline & Thermal activity, resetting & $1.72 \mathrm{Ga}$ & $\begin{array}{l}\text { posttectonic "A type" } \\
\text { granitoid suites }\end{array}$ & $1.72 \mathrm{Ga}$ & $\begin{array}{l}\text { posttectonic "A type" } \\
\text { granitoid suites; possible } \\
\text { coeval felsic volcanics }\end{array}$ \\
\hline $\begin{array}{l}1.74 \mathrm{Ga} \\
1.80 \mathrm{Ga}\end{array}$ & $\begin{array}{l}\text { of titanite ages } \\
\text { Latest movements on } \\
\text { Kanairiktok Shear Zone }\end{array}$ & $1.78 \mathrm{Ga}$ & $\begin{array}{l}\text { latest movements on } \\
\text { Kaipokok Bay shear } \\
\text { zones }\end{array}$ & & \\
\hline $\begin{array}{l}1.81 \text { to } \\
1.79 \mathrm{Ga}\end{array}$ & $\begin{array}{l}\text { Granitoid magmatism of } \\
\text { syntectonic and posttectonic } \\
\text { setting }\end{array}$ & $\begin{array}{l}1.81 \text { to } \\
1.79 \mathrm{Ga} \\
1.81 \mathrm{Ga}\end{array}$ & $\begin{array}{l}\text { granitoid magmatism of } \\
\text { syntectonic and } \\
\text { posttectonic setting } \\
\text { Youngest Upper Aillik } \\
\text { Group felsic volcanism }\end{array}$ & $\begin{array}{l}1.81 \text { to } \\
1.79 \mathrm{Ga}\end{array}$ & $\begin{array}{l}\text { voluminous and varied } \\
\text { granitoid magmatism of } \\
\text { syntectonic and post- } \\
\text { tectonic setting }\end{array}$ \\
\hline $\begin{array}{l}1.83 \text { to } \\
1.82 \mathrm{Ga}\end{array}$ & $\begin{array}{l}\text { NW-directed thrusting, fol- } \\
\text { lowed by upright folding, } \\
\text { and widespread dextral } \\
\text { shearing }\end{array}$ & $? ? ? ?$ & deformation & & \\
\hline \multirow[t]{2}{*}{$1.835 \mathrm{Ga}$} & Development of shear zones & & & $1.84 \mathrm{Ga}$ & $\begin{array}{l}\text { earliest dated granitoid } \\
\text { plutonism }\end{array}$ \\
\hline & Granitoid plutonic suites & $1.86 \mathrm{Ga}$ & $\begin{array}{l}\text { earliest Upper Aillik } \\
\text { Group felsic volcanism } \\
\text { granitoid plutonic suites }\end{array}$ & $? ? ? ?$ & $\begin{array}{l}\text { supracrustal rocks equiva- } \\
\text { lent to Upper Aillik } \\
\text { Group? }\end{array}$ \\
\hline $1.88 \mathrm{Ga}$ & $\begin{array}{l}\text { Earliest recognized thrusting } \\
\text { in supracrustal rocks, trans- } \\
\text { lation of unconformity }\end{array}$ & $1.88 \mathrm{Ga}$ & $\begin{array}{l}\text { juxtaposition of Lower } \\
\text { Aillik Group and } \\
\text { Archean basement }\end{array}$ & & \\
\hline $1.89 \mathrm{Ga}$ & $\begin{array}{l}\text { Emplacement of potassic } \\
\text { granitoid rocks }\end{array}$ & & & $? ? ? ?$ & $\begin{array}{l}\text { deformation and metamor- } \\
\text { phism of Cape Harrison }\end{array}$ \\
\hline $1.90 \mathrm{Ga}$ & $\begin{array}{l}\text { Metamorphosed and rework- } \\
\text { ing of diabase dyke swarm }\end{array}$ & & & & Metamorphic Suite \\
\hline$>1.90 \mathrm{Ga}$ & $\begin{array}{l}\text { Deposition of supracrustal } \\
\text { rocks, mafic volcanism }\end{array}$ & $>1.90 \mathrm{Ga}$ & $\begin{array}{l}\text { deposition of Lower Aillik } \\
\text { Group supracrustal rocks }\end{array}$ & $<2.1 \mathrm{Ga}$ & $\begin{array}{l}\text { formation of protoliths } \\
\text { to Cape Harrison } \\
\text { Metamorphic Suite }\end{array}$ \\
\hline $2.23 \mathrm{Ga}$ & $\begin{array}{l}\text { Emplacement of Kikkertavak } \\
\text { diabase dyke swarm }\end{array}$ & $? ? ? ?$ & $\begin{array}{l}\text { basement enclaves of } \\
\text { uncertain age and } \\
\text { affinity }\end{array}$ & & orthogneisses \\
\hline $2.84 \mathrm{Ga}$ & Tonalitic plutonic suites & & & & \\
\hline $3.10 \mathrm{Ga}$ & $\begin{array}{l}\text { Oldest recognized Archean } \\
\text { gneisses }\end{array}$ & $3.10 \mathrm{Ga}$ & $\begin{array}{l}\text { basement rocks that resem- } \\
\text { ble Archean gneisses of } \\
\text { Kaipokok Domain }\end{array}$ & & \\
\hline
\end{tabular}


Table 1. (continued)

\begin{tabular}{|c|c|c|c|c|c|}
\hline \multicolumn{6}{|c|}{ Ketilidian Mobile Belt of South Greenland } \\
\hline & Border Zone & & Julianehảb Batholith & & Psammite-Pelite Zone \\
\hline $\begin{array}{l}1.77 \text { to } \\
1.72 \mathrm{Ga}\end{array}$ & $\begin{array}{l}\text { Emplacement of granitoid } \\
\text { plutons into basement rocks }\end{array}$ & $\begin{array}{l}1.76 \text { to } \\
1.74 \mathrm{Ga}\end{array}$ & $\begin{array}{l}\text { emplacement of late, } \\
\text { rapakivi type granitoid } \\
\text { plutons }\end{array}$ & $\begin{array}{l}1.76 \text { to } \\
1.74 \mathrm{Ga}\end{array}$ & $\begin{array}{l}\text { emplacement of late, } \\
\text { rapakivi type granitoid } \\
\text { plutons }\end{array}$ \\
\hline \multirow[t]{4}{*}{$\begin{array}{l}1.81 \text { to } \\
1.79 \mathrm{Ga}\end{array}$} & & & & $\begin{array}{l}1.79 \text { to } \\
1.78 \mathrm{Ga}\end{array}$ & $\begin{array}{l}\text { emplacement of } \\
\text { "syntectonic" and anatectic } \\
\text { granitoid rocks }\end{array}$ \\
\hline & $\begin{array}{l}\text { (Detailed history } \\
\text { unknown) }\end{array}$ & 1.82 to & granitoid oluton & $1.79 \mathrm{Ga}$ & $\begin{array}{l}\text { latest detrital zircon grain } \\
\text { recognized in psammites }\end{array}$ \\
\hline & & $1.81 \mathrm{Ga}$ & $\begin{array}{l}\text { central part of the } \\
\text { batholith, sinistral } \\
\text { transpression }\end{array}$ & $1.82 \mathrm{Ga}$ & $\begin{array}{l}\text { age of granitoid cobble } \\
\text { in Psammite Zone } \\
\text { conglomerate }\end{array}$ \\
\hline & & $1.84 \mathrm{Ga}$ & $\begin{array}{l}\text { earliest dated granitoid } \\
\text { plutonism, southern part } \\
\text { of batholith }\end{array}$ & $\begin{array}{l}1.84 \text { to } \\
1.80 \mathrm{Ga}\end{array}$ & $\begin{array}{l}\text { main population of detrital } \\
\text { zircon grains in psammites }\end{array}$ \\
\hline$? ? ? ?$ & Later upright folding & ???? & $\begin{array}{l}\text { formation of sedimentary } \\
\text { and felsic volcanic rocks } \\
\text { of the Ilordleq Group }\end{array}$ & & $\begin{array}{l}\text { (detailed history } \\
\text { unknown) }\end{array}$ \\
\hline ???? & $\begin{array}{l}\text { NW directed thrusting and } \\
\text { translation of basement- } \\
\text { cover unconformity } \\
\text { (Detailed history } \\
\text { unknown }\end{array}$ & & $\begin{array}{l}\text { (detailed history } \\
\text { unknown) }\end{array}$ & & \\
\hline$? ? ? ?$ & \multicolumn{2}{|l|}{$\begin{array}{l}\text { Deposition of Vallen and Sortis } \\
\text { Group supracrustal rocks }\end{array}$} & & $1.96 \mathrm{Ga}$ & $\begin{array}{l}\text { oldest detrital zircon grain } \\
\text { recognized in psammites }\end{array}$ \\
\hline $2.13 \mathrm{Ga}$ & $\begin{array}{l}\text { Emplacement of Iggavik } \\
\text { diabase dyke swarm (Rb-Sr, } \\
\text { approximate age only) }\end{array}$ & & & & \\
\hline $\begin{array}{l}3.2 \text { to } \\
2.8\end{array}$ & $\begin{array}{l}\text { Formation and stabilization } \\
\text { of Archean basement complex } \\
\text { of southern Greenland }\end{array}$ & & & & \\
\hline
\end{tabular}

For details of sources, see text. 


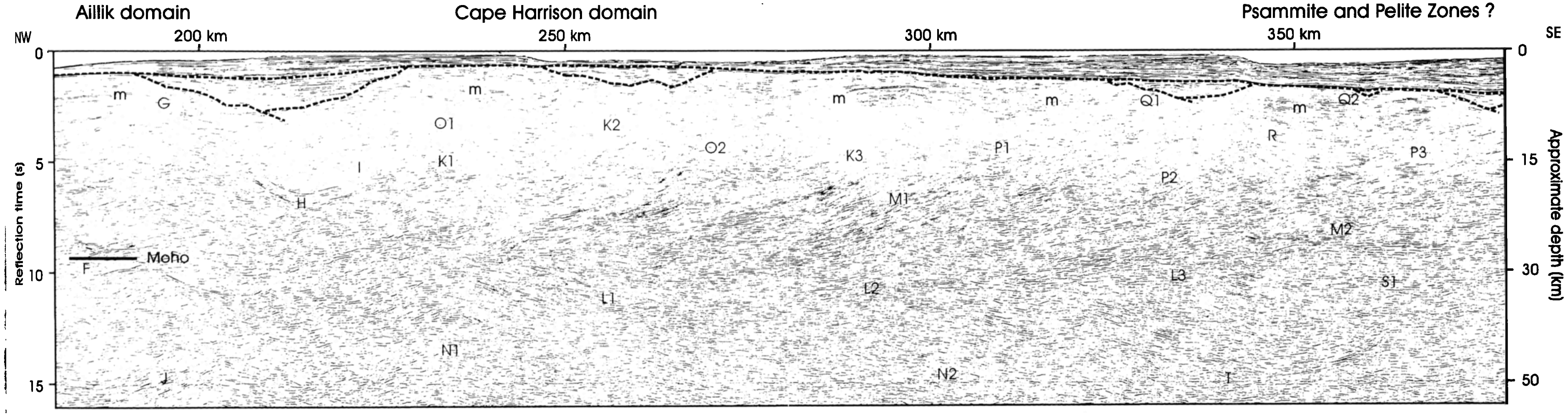

Plate 1. Seismic reflection profile from the critical central region of the Makkovikian - Ketilidian Orogenic Belt, from $\mathrm{km} 180$ to $\mathrm{km} 330$ (approximately). Features designated by letters are also indicated on Figure 4. Moho position is after Reid [1996]. 



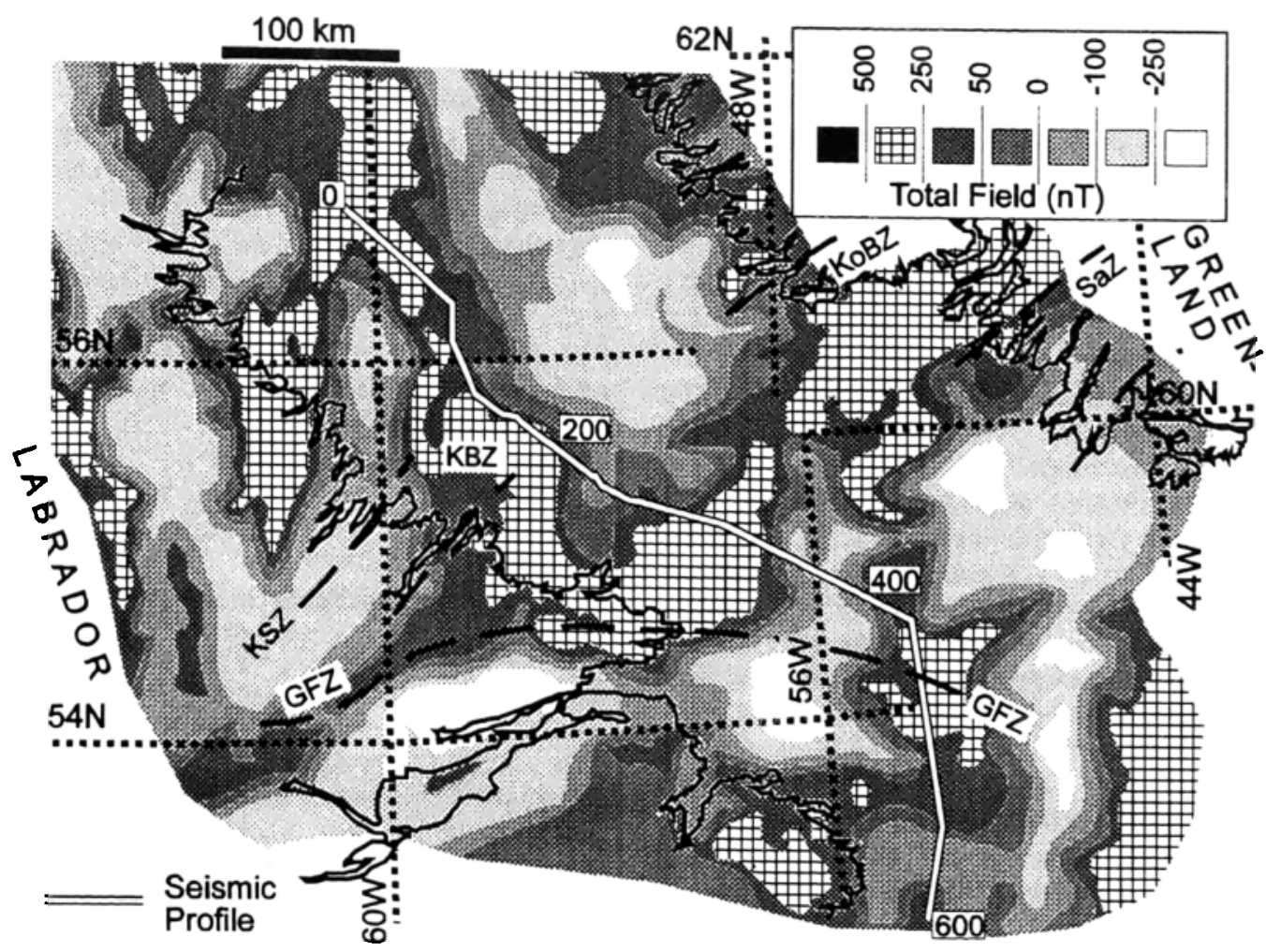

(a) Total Magnetic Field

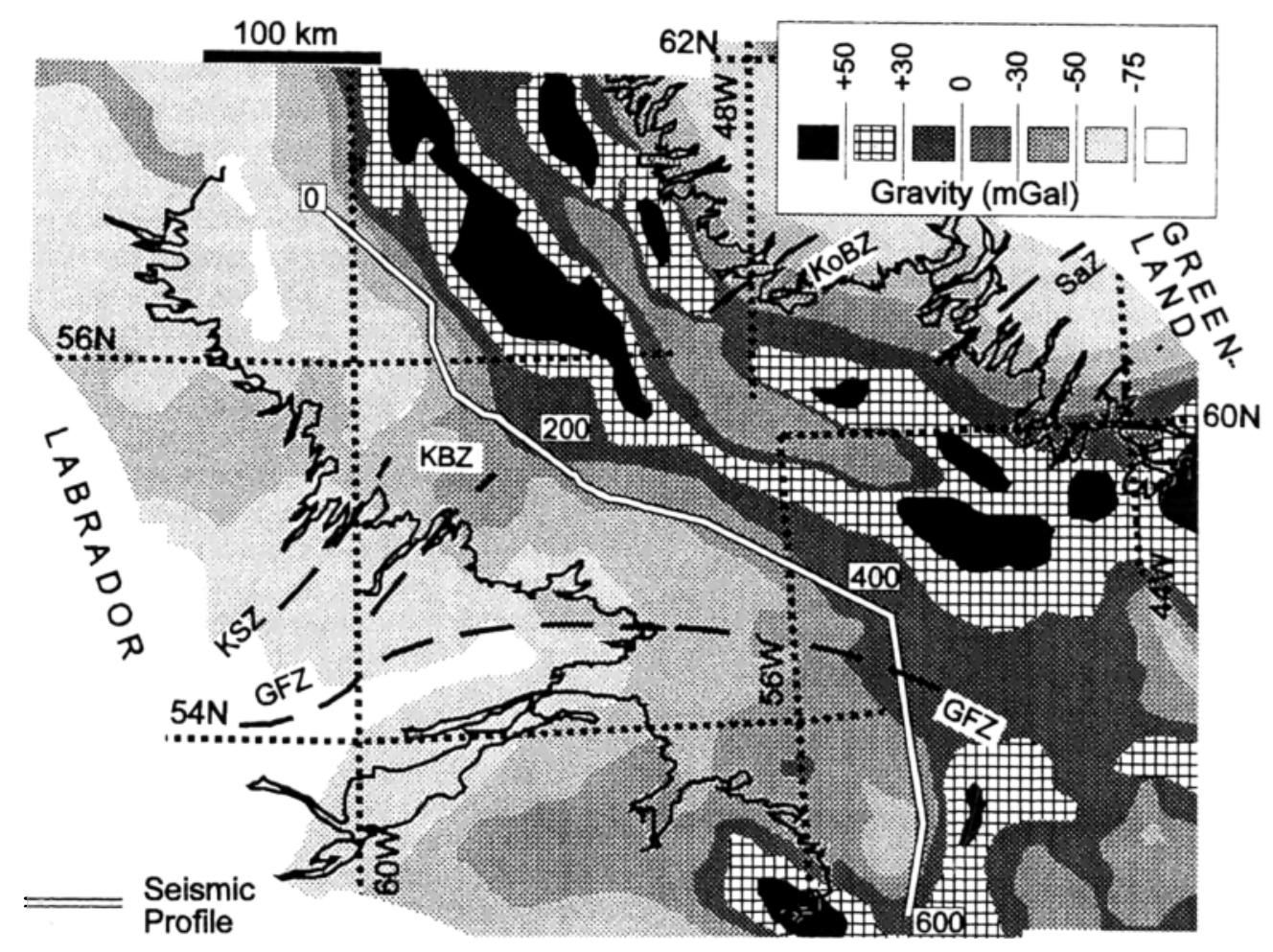

\section{(b) Bouguer Gravity Anomaly}

Figure 3. (a) Total field magnetic anomaly map for the reconstructed Labrador Sea region, showing reconstructed coastlines and major geological features. (b) Bouguer gravity anomaly map for the reconstructed Labrador Sea region, showing reconstructed coastlines and major geological features. Both maps are simplified from Srivastava and Roest [1989]. 
[Allaant, 1976] or Julianehåb Batholith [Chadwick et al., 1994] in the Ketilidian belt (Figure 2). This major plutonic terrane is characterized by a prominent aeromagnetic high that extends across both continental shelves and appears to be truncated along the Grenville Front (Figure 3a).

In Labrador, the oldest identified rocks are gneisses of the Cape Harrison Metamorphic Suite (Figure 2) which, on the basis of Nd studies, are unlikely to be older than $\sim 2.1 \mathrm{Ga}$ [Kerr and Fryer, 1993, 1994]. Foliated 1.84- to 1.80-Ga granitoid rocks, and massive suites of 1.80-, 1.72- and 1.65$\mathrm{Ga}$ age are also recognized [Kerr et al., 1992]; the 1.80-Ga group is also present offshore (Figure 2) in wells ELS-51, ELS-53, and ELS-68 [Wasteneys et al., 1992]. The youngest $(1.65 \mathrm{Ga})$ suites are probably related to subsequent events within the Labradorian Orogen to the south [e.g., Gower et $a l ., 1990]$. The older suites are potassic, compositionally evolved monzonites, syenites, and granites which are transitional between so-called "I type" and "A type" granites. These are dissimilar to younger arc-type batholiths but resemble Appalachian postorogenic suites [Kerr, 1989a; Kerr et al., 1996]. Nd isotopic studies of these rocks, which are dominated by 1.8-Ga intrusions [Kerr and Fryer, 1994] indicate that Archean crust of the North Atlantic Craton does not extend far beyond the eastern limit of the Aillik Domain (Figure 2). Nd isotopic data from offshore well intersections [Kerr and Wardle, 1997] suggest that the equivalent isotopic boundary lies between $\mathrm{km} 160$ and $\mathrm{km} 200$ near the seismic profile between wells ELS-69/90 and ELS-62/53 (Figure 2).

In Greenland, the Julianehasb Batholith increases from 40 $\mathrm{km}$ wide in the east to over $100 \mathrm{~km}$ wide on the west coast and includes several subparallel zones of foliated granites and more massive suites. Largely unfoliated ("late") granites compose about $70 \%$ of the batholith, particularly in the north [Allaart, 1976; Kalsbeek et al., 1990], but recent descriptions [Chadwick et al., 1994] suggest that penetrative fabrics may be more widespread in the south. Chadwick and Garde [1996] suggest that much of the batholith was emplaced in a regime of sinistral transpression, which contrasts with the largely dextral transpression inferred for the Kaipokok Bay Zone in Labrador (Culshaw and Ketchum, 1994). The region also includes mafic intrusive complexes, characterized by hydrous gabbros and diorites, which have ambiguous intrusive relationships with the granitoid rocks, suggesting to Kalsbeek et al. [1990] that they were in part coeval. U-Pb ages of 1.85 $\mathrm{Ga}, 1.80 \mathrm{Ga}$ and $1.75 \mathrm{Ga}$ [van Breemen et al., 1974; Gulson and $\mathrm{Krogh}, 1975]$ resemble the age distribution noted by Kerr et al. [1992] but are less precise. More recent dating suggests an important magmatic pulse at $\sim 1.82 \mathrm{Ga}$ [Hamilton et al., 1995]. Southward shifts in the $\mathrm{Pb}, \mathrm{Sr}$, and $\mathrm{Nd}$ isotopic compositions of Ketilidian granites indicate that Archean crust does not occur very far south of the Kobberminebugt Zone [Patchett and Bridgwater, 1984; Kalsbeek and Taylor, 1985; Hamilton et al., 1995]. Although the Julianehab Batholith is widely described as "Andean" [e.g., Bridgwater et al., 1973; Allaart, 1976; Windley, 1991; Chadwick and Garde, 1996], there are few geochemical data available for comparison either with Labrador or modern analogues.

\subsection{Sardloq Shear Zone (Greenland)}

The Julianehåb Batholith includes several ductile shear zones [Chadwick et al., 1994]. The most prominent is the 1- to 2-km-wide Sardloq Zone (Figure 2), where ultramylonites derived from granitoid rocks show subhorizontal lineations and evidence of sinistral transcurrent motion [Chadwick et al., 1994]. Mylonitized granites south of the shear zone appear to have been sites of anatectic melting [Chadwick et al., 1994]. Chadwick and Garde [1996] note that the shear zone does not define the southern limit of the batholith at the surface, as previously suggested [Bridgwater et al., 1973; Windley, 1991], but it must be important, as it coincides with a prominent break in the aeromagnetic pattern, perhaps indicative of contrasting granitoid associations (Figure 3a). The continuity of the magnetic high associated with the batholith suggests that the Sardlog Zone should cross the continental shelf some $50 \mathrm{~km}$ off Labrador, east of the onshore portion of the Makkovikian Orogen (Figure 3a).

\subsection{Psammite and Pelite Zones (Greenland)}

Southermmost Greenland comprises the "folded migmatite" and "flat-lying migmatite" zones of Allaart [1976], for which Chadwick and Garde [1996] use the names Psammite and Pelite Zones, respectively (Figure 2). This terminology conveys the dominance of metasedimentary gneisses in strong contrast to the adjacent Julianehảb Batholith. Southernmost Greenland coincides with a prominent aeromagnetic low, which continues across both continental shelves but does not extend into the onshore (Figure 3a). Orthogneisses intersected by offshore wells ELS-51 and ELS-68 yielded $\sim 1.80 \mathrm{Ga}$ U-Pb ages [Wasteneys et al., 1992], confirming the existence of Makkovikian - Ketilidian crust in the offshore region, but no metasedimentary rocks were intersected.

The Psammite Zone is dominated by amphibolite to granulite-facies psammitic paragneiss, with lesser amphibolites and orthogneiss units [Kalsbeek et al., 1990; Chadwick and Garde, 1996]. The nature of any basement to the psammite zone is unclear, and banded gneisses reported by Allaart [1976] may be strongly migmatized metasediments [Chadwick and Garde, 1996]. On the basis of granitoid clasts in metaconglomerates, it has been suggested that many of these rocks are younger than (and perhaps derived from) the granitoid batholith to the north [Chadwick et al., 1994]. An age of $1.82 \mathrm{Ga}$ from a granite cobble [Hamilton et al., 1995] supports this idea, and well-preserved metasediments contain detrital zircons dated at 1.96 to $1.79 \mathrm{Ga}$ [Hamilton et al., 1996]. The 1.79-Ga detritus provides a maximum age for deposition, but it is not certain that these ages apply to all metasedimentary rocks in the region. The Pelite Zone is dominated by pervasively migmatized pelitic gneisses, with gently dipping to subhorizontal layering and foliation. The pelitic gneisses are interlayered with minor marble, calcsilicate rocks, and amphibolites [Allaart, 1976] and subconcordant sheets of garnetiferous granite, presumably of anatectic origin. The Psammite and Pelite Zones were also affected by extensive late-stage magmatism, typified by fayalite and orthopyroxene-bearing "rapakivi suites," including norite, monzonite, syenite, and granite (s.s.). These have been interpreted as diapiric mushroom-like bodies [Bridgwater et al., 1973] or as sheet-like bodies associated with extensional ductile shear zones [Hutton et al., 1990]. $\mathrm{U}-\mathrm{Pb}$ ages of 1.76-1.74 Ga [Gulson and Krogh, 1975] from these intrusions indicate that they are younger than much of the Julianehàb Batholith, and they have largely "juvenile" Nd 
isotopic signatures [Patchett and Bridgwater, 1984]. Syntectonic granites examined by Hamilton et al. [1996] gave ages of 1.79 to $1.78 \mathrm{Ga}$, implying that deformation is relatively young.

The Psammite and Pelite Zones exhibit a distinct structural pattern [Allaart, 1976]. Steeply dipping to subvertical structures, with complex interference patterns, predominate in the north but become flatter toward the south. There is evidence for early southeast verging recumbent fold structures on both the east and west coasts of Greenland and for later upright folding [Allaart, 1976; Chadwick and Garde, 1996]. The southern tip of Greenland has been interpreted as a gentle domal structure [Bridgwater et al., 1973], possibly representing a large-scale nappe [Windley, 1991]. Metamorphism in the Psammite and Pelite Zones represents low-pressure, high-temperature conditions, with abundant sillimanite and andalusite; estimates of $2-4 \mathrm{Kbars}$ and $650^{\circ}-850^{\circ} \mathrm{C}$ indicate very high geothermal gradients [Dempster et al., 1991]. A 1.78-Ga age from an anatectic granite indicates that this metamorphism is significantly younger than metamorphism in the north of the orogen, interpreted to be largely synchronous with 1.82-Ga granitoid rocks [Hamilton et al., 1995].

\subsection{Younger Igneous and Sedimentary Rocks}

In the Nain Province (Figure 2), there are abundant Middle Proterozoic (1.46 - 1.23 Ga) mafic, anorthositic, and granitic plutons presumed to be associated with crustal extension and rifting [e.g., Emslie, 1978]. Plutonic rocks of similar age, including alkaline granites, also occur within the Ketilidian Orogen (Figure 2), where they form the Gardar Province. A 1.27-Ga age from offshore well ELS-56 [Wasteneys et al., 1992] indicates that these intrusions may also be present near the seismic profile (Figure 2).

\subsection{Summary of Tectonic Zonation}

The Makkovikian - Ketilidian Orogen is divisible into several discrete tectonic zones. Working outward from the North Atlantic Craton, these are as follows:

1. There is a zone of reworked Archean basement rocks, variably deformed Early Proterozoic supracrustal sequences, and subordinate plutonic rocks. In Labrador, this zone has a complex early history, including 1.89 - to 1.87 -Ga granitoid plutonism and early (pre-1.87 Ga) juxtaposition of basement and cover, with superimposed 1.80-Ga deformation and magmatism. The latest deformations, at least, involved northwest directed thrusting. The equivalent region in Greenland may share this early history, but as it has received limited attention since the 1970 s, geochronological data are sparse.

2. There is a shear zone in which basement and supracrustal rocks akin to those of the above zone are strongly deformed and juxtaposed with younger supracrustal rocks (see below). In Labrador, there was early, pre-1.86-Ga deformation, but most of the deformation occurred $\sim 1.8 \mathrm{Ga}$ ago. This zone apparently delimits the surface extent of Archean basement in both Labrador and Greenland and may represent a suture.

3. There is a zone dominated by felsic volcanic rocks and younger plutons, which is well preserved in Labrador but more deeply eroded in Greenland. Some of the felsic volca- nism occurred $~ 1.86 \mathrm{Ga}$ ago, but some was probably coeval with 1.81- to 1.80-Ga granitoid plutonism, prevalent to the southeast.

4. There is a zone dominated by complex plutonic suites, with few remnants of supracrustal rocks. In Labrador, this includes $1.84-\mathrm{Ga}, 1.80-\mathrm{Ga}$, and $1.72-\mathrm{Ga}$ assemblages, with affinities to Paleozoic and younger postorogenic magmatic suites. However, early members and gneissic enclaves may represent earlier arc-type rocks. In Greenland, 1.82- to 1.80$\mathrm{Ga}$ plutonic rocks are viewed as arc related, although geochemical data are lacking and 1.74-Ga plutonic assemblages of "rapakivi" type are also recognized. The $1.65-\mathrm{Ga}$ mafic and granitoid suites are recognized in Labrador but apparently not in Greenland. Isotopic signatures on both sides of the Labrador Sea indicate that there is no Archean basement beneath this zone.

5. There is a zone dominated by metasedimentary gneisses and granitoid rocks, preserved only in south Greenland. At least some psammitic rocks probably had sources within the magmatic belt to the north and were deformed and metamorphosed after $1.78 \mathrm{Ga}$, but the region may include more than one group of supracrustal rocks. Major structures in this zone are south verging, in contrast to those documented in the north. Extensive 1.75- to $1.74-\mathrm{Ga}$ granitoid plutonism of postorogenic, "rapakivi" type implies an extended thermal history throughout this zone. As far as is known, the metasedimentary rocks had largely "juvenile" sources, and there is little direct or indirect evidence for older continental basement.

In summary, the Makkovikian - Ketilidian province may not preserve a complete cross section through an orogenic belt, but it includes crustal regions with very different histories and a first-order crustal boundary between Archean and juvenile Proterozoic crust. This tectonic zonation across the orogen should be documented by progressive changes in crustal reflectivity patterns, as revealed by the seismic reflection profile, discussed below.

\section{Seismic Reflection Profile}

\subsection{Location and Representation}

The ECSOOT profile lies 40 to $120 \mathrm{~km}$ from the coastline of Labrador and 100 to $150 \mathrm{~km}$ from the restored Greenland coast (Figure 2); if the effects of prerifting stretching are removed [cf. Srivastova and Verhoef, 1992], the coastlines would be approximately equidistant from the line. The profile lies landward of significant crustal extension associated with the formation of the Labrador Sea [Hall et al., 1995] (Figure 3b). This paper discusses the profile from $\mathrm{km} 0$, a point well within the Archean craton to beyond $\mathrm{km} 450$, a location that may represent the Grenville Front [Hall et al., 1995]. Regional structural patterns in both Labrador and Greenland are oriented roughly at $90^{\circ}$ to the seismic line, suggesting that dipping structures should show approximate true dips assuming that they strike parallel to regional trends. In this paper, we use the phrases "northwest dipping" and "southeast dipping" to refer to reflector orientations, but we recognize that in some cases these may be apparent dip directions and magnitudes. 


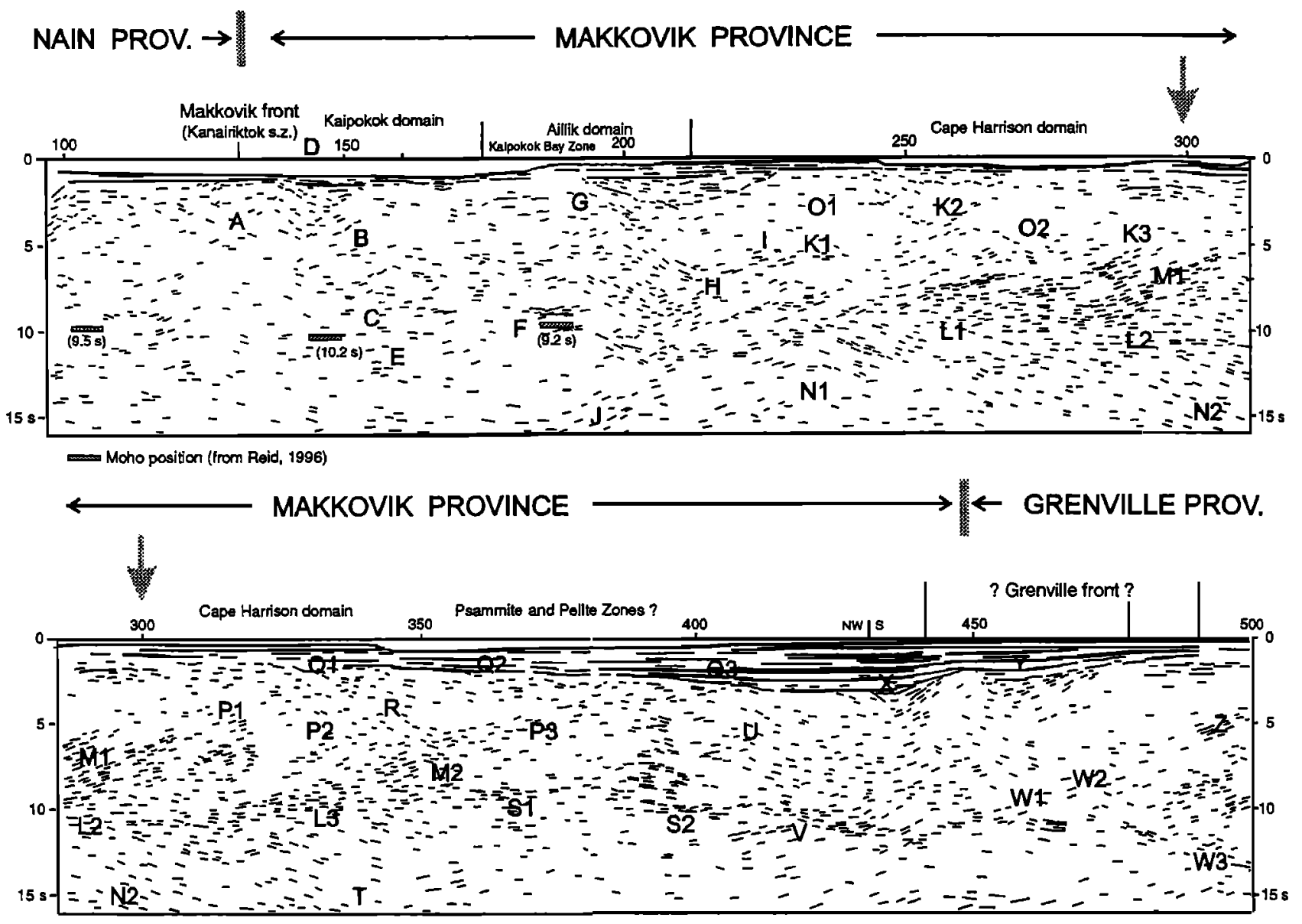

Figure 4. Line drawings of southem ECSOOT seismic reflection profile, adapted from Hall et al. [1995]. For details of acquisition and processing, see Hall et al. [1995]. Moho position is after Reid [1996]. Note that the two halves of the diagram incorporate some $30 \mathrm{~km}$ of overlap to aid in linking them. Features designated by letters are also indicated on Plate 1.

Full details of line positioning, data acquisition and processing, original seismic profiles, and a regional analysis of data from the entire ECSOOT profile (Figure 1) are presented by Hall et al. [1995]. Line-segment diagrams after Hall et al. [1995] are presented at a reduced scale as a basic framework for discussion. The most important section of the profile, from $\mathrm{km} 180$ to $\mathrm{km} 380$, has been reprocessed with much stronger coherency filters and a higher gain than used by Hall et al. [1995], in order to better illustrate reflection fabrics critical to this paper (Plate 1). A "brighter" plot results, with the minor disadvantage that it is more difficult to see reflections in low-amplitude parts of the section. The line drawings and profile are drawn without vertical exaggeration for a seismic velocity of $6 \mathrm{~km} / \mathrm{s}$, consistent with estimates of Chian and Louden [1992]. Reflector groups are designated by letters $A-Z$, qualified by numbers where necessary, on the line drawings (Figure 4) and original profile (Plate 1).

\subsection{Nain Province and Kaipokok Domain}

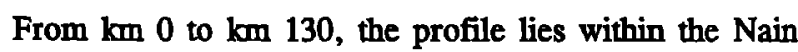
Province (Figure 2). This generally unreflective region is described and discussed elsewhere [Hall et al., 1995]. The Kanairiktok Shear Zone should intersect the seismic line at about $\mathrm{km} 125$ (Figure 2). However, there is no clear break in reflector patterns at this point (label A) and no suggestion of a major dipping structure. The profile through the Kaipokok Domain (km 130 to $\mathrm{km} 190)$ is similar to the adjacent Nain Province. Reflector patterns are generally weak and inconsistent, although there is a northwest dipping domain around $\mathrm{km}$ 150 (label B) and possibly more widespread subhorizontal reflectivity in the lower crust from $\mathrm{km} 150$ to 190 (label C). In the case of $B$, there may be a mimetic link to a small sedimentary basin visible in the upper few seconds (label $D$ ). The base of the crust in this region lies at $9.5-10.2 \mathrm{~s}$, as determined from coincident wide-angle seismic experiments (indicated on Figure 4) [Reid, 1996]. Sporadic subhorizontal to northwest dipping reflectivity is present at $10-15 \mathrm{~s}$, particularly approaching the inferred location of the Kaipokok Bay Zone (labels E and F). As noted by Hall et al. [1995], this has a similar orientation to reflectivity in the middle crust beyond $\mathrm{km} 200$ (labels K1 and K2).

\subsection{Kaipokok Bay Zone, Aillik Domain, and Cape Harrison Domain}

Extrapolation of the Kaipokok Bay Zone to meet the Kobberminebugt Zone suggests that this structure should cross 
the line around $\mathrm{km} 180$ to 190 (Figure 2, see later discussion). This corresponds with southeast dipping upper crustal reflectors (label G) apparently bounding and below an overlying sedimentary basin. At deeper levels, there are scattered southeast dipping reflectors (between labels $\mathbf{G}$ and $\mathrm{H})$, forming a zone that may extend downward to link with the deep reflectors $\mathrm{N} 1$. The discrete bright reflections at label $\mathrm{H}$ may be part of this zone but could partly represent multiples of overlying basins and/or migration smiles. There is no clear truncation relationship between the southeast dipping reflectivity and the wider zone of northwest dipping reflections that dominate the profile to the southeast (see below). Refraction data indicate that the base of the crust lies at around $9.5-10.2 \mathrm{~s}$ in this part of the profile (indicated on Figures 4 and 5) [Reid, 1996], and it is likely represented by subhorizontal reflectivity (labels $\mathrm{C}$ and $\mathrm{F}$ ). Below this, northwest dipping reflectivity extends to depths below $15 \mathrm{~s}$ (label $\mathrm{J}$ ) and is assumed to be at mantle depths.

The character of the seismic section changes significantly beyond $\mathrm{km} 190$ (near surface) and $\mathrm{km} 215$ (at $10 \mathrm{~s}$ ). The diffuse southeast dipping reflector (labels $\mathbf{G}$ and $\mathrm{H}$ ) merges into a more diffuse zone of reflectivity at around $\mathrm{km} 220$ at depths of $7 \mathrm{~s}$. Beyond this point, the middle crust shows a northwest dipping reflectivity (labels $\mathrm{K} 1, \mathrm{~K} 2$, and $\mathrm{K} 3$ ), and there is a strongly reflective lower crust from about $7 \mathrm{~s}$ to 10 s. Deeper parts of the section are characterized by southeast dipping reflectivity, extending to $15 \mathrm{~s}$ (labels $\mathrm{N} 1, \mathrm{~N} 2$, and N3). The base of the crust beneath the Cape Harrison Domain has not been located from coincident wide-angle seismic experiments, but its position may be estimated from other data. Modeling of data recorded at a nearby coastal land site suggests a Moho reflection time of $12 \mathrm{~s}$ midway between the profile and the coast [Louden and Fan, 1997], greater than the 9.5- to 10.2-s estimate near the Makkovik Front [Reid, 1996]. Coincident normal incidence and wide-angle data perpendicular to the ECSOOT profile, and linked to it near $\mathrm{km} \mathrm{150,}$ indicate that crustal thinning is largely restricted to areas outboard of the profile [Chian and Louden, 1992; Keen et al., 1994], although it may have affected the crust in areas where

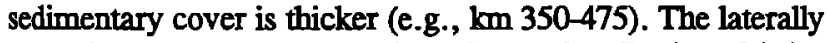
extensive, but opposed, orientations of reflection fabrics above $10 \mathrm{~s}$ and from $11 \mathrm{~s}$ to $15 \mathrm{~s}$ (Figure 4) strongly suggest that the intervening depth range includes a significant boundary, and interpretation as the Moho is consistent with the wide-angle data. This indicates a crustal thickness slightly greater than in the area of the Makkovik Front [Reid, 1996]. In contrast to the middle and lower crust, the upper crust throughout this region (above $6 \mathrm{~s}$ ) is in general fairly transparent but shows some sporadic northwest and southeast dipping reflectors (labels $\mathrm{O} 1$ and 02 ).

The lower crustal region from about $\mathrm{km} 220$ to $\mathrm{km} 250$ appears to be a "focal point" for divergent crustal and mantle reflectivity patterns. To the northwest, southeast dipping crustal reflectivity opposes a deeper northwest dipping mantle reflectivity; to the southeast, the pattern is reversed, with northwest dipping structure in the crust and southeast dipping reflectors in subjacent mantle.

\subsection{Psammite and Pelite Zones of Southernmost Greenland}

Regional geological and geophysical correlations imply that the profile beyond $\mathrm{km} 320$ should image crust corresponding to southernmost Greenland (Figures 2 and 3a). This portion of the line is well offshore, as indicated by the thicker Mesozoic - Tertiary sedimentary section, but is landward of the axial positive gravity anomaly of the plate reconstruction (Figure 3b). The seismic profile from $\mathrm{km} 300$ to $\mathrm{km} 400$ is probably the most strongly reflective segment of the cross section (Plate 1). Northwest dipping reflective zones (labels P1, P2, and P3) appear to "sole" into the strongly reflective lower crust noted above (labels $L$ and $M$ ). Northwest dipping zones intersect the Mesozoic unconformity at $\mathrm{km} 340, \mathrm{~km}$ 370 , and $\mathrm{km} 400$ (labels Q1, Q2, and Q3), where they are spatially associated with small Mesozoic - Cenozoic basins. There is also a less obvious southeast dipping reflectivity in the upper crust (label R). At depth, these northwest dipping zones coalesce with a strong zone of subhorizontal reflectivity at around $10 \mathrm{~s}$ (labels S1 and S2), which here shows mostly subhorizontal orientation. The base of the crust is inferred to lie around $10 \mathrm{~s}$, based on results of Chian and Louden [1992] and is underlain by an opposing, southeast dipping, reflectivity (label T). This mantle reflectivity is continuous with similar reflectors noted previously (labels N1 and N2) but appears stronger, particularly around $\mathrm{km} 330$.

The final section of the profile extends from $\mathrm{km} 400$ to

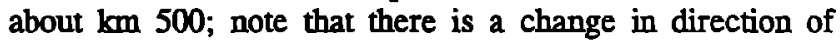
approximately $30^{\circ}$ at about $\mathrm{km} 430$ (Figure 2). This portion of the profile is over $120 \mathrm{~km}$ offshore from Labrador and the restored Greenland coast. The Mesozoic - Cenozoic sedimentary section is thicker and more continuous here than elsewhere on the profile, and its thickness is inversely correlated with the apparent thickness of the crust [Hall et al., 1995]. Thus this region may have been affected by extension associated with the formation of the Labrador Sea. Northwest dipping reflectivity discussed above is less obvious here, although still visible (e.g., label $U$ ). There is also strong subhorizontal reflectivity in the lower crust (label V). Discontinuous southeast dipping structures that project to the surface around $\mathrm{km} 430$ - $\mathrm{km} 450$ (labels W), associated with sedimentary basins (labels $X$ and $Y$ ), were interpreted by Hall et al. [1995] as a potential location for the Grenville Front and mark the southern limit of interpretation in this paper. Note, however, that northwest dipping reflectivity is visible south of these structures (label Z).

\section{Interpretation of Seismic Reflection Profile}

\subsection{Age and Significance of Reflector Packages}

The reflector packages discussed in this paper are interpreted to be related to collisional and/or accretionary orogenic processes of Proterozoic age, but an alternative interpretation, that is, that these fabrics relate to Mesozoic or younger extension associated with formation of the Labrador Sea must also be considered and discussed. However, we consider this unlikely for several reasons. 
The dipping reflections are of crustal scale and, although they are most obvious in the middle and lower crust, they can be traced through the upper crust to the sub-Mesozoic unconformity, where they die out. There are isolated examples of major basement structures that appear to control sedimentary basins (e.g., at the Kaipokok Bay Zone and proposed Grenville Front), suggesting their local reactivation, but most basement reflectivity appears to be truncated by the rift-drift unconformity. The position of the ECSOOT profile was carefully selected (using abundant petroleum industry data for the Labrador shelf) to lie landward of major extensional faults in the continental margin basins, except at the southernmost end of the section discussed in this paper, and the sedimentary veneer is generally thin, which limits the magnitude of any extension. There are a few areas where sediment thicknesses approach $3 \mathrm{~s}$, but this is still less than half of the sediment thickness in deeper marginal basins. Aside from the distal section from $\mathrm{km} 400 \mathrm{ko} \mathrm{km} \mathrm{510,} \mathrm{there}$ is no apparent inverse correlation between crustal thickness and the depth of sedimentary basins, and there is no correlation between the intensity of crustal reflection fabrics and the thickness of the overlying sedimentary basins, where present. Finally, there is no indication from the trans-Labrador Sea survey of Keen et al. [1994] that the pattern of basement extension is laterally displaced from more obvious upper crustal development of major sedimentary basins. Thus, in conjunction with the evidence from wide-angle seismic surveys [Chian and Louden, 1992; Reid, 1996] and the transLabrador Sea line [Keen et al., 1994], we believe that Mesozoic extensional effects here are minor and that the bulk of the crustal architecture is of Proterozoic age. However, we do accept that some of the more prominent reflector packages may have been reactivated as extensional structures, either during Proterozoic postorogenic collapse or during much younger rifting associated with the Labrador Sea.

\subsection{General Features}

The profile can be subdivided into two halves, shown schematically in Figure 5. The northwestern portion, from $\mathbf{k m}$ 0 to $\mathrm{km} 190$ (approximately) has a weakly and inconsistently reflective crust. This type of structure, or rather a lack of it, is also typical of the Nain Province as imaged by the northern ECSOOT profile [Hall et al., 1995] and appears to be a general characteristic of this region. The Kaipokok Domain and Border Zone in Greenland are affected by pervasive Proterozoic structural reworking, but there is little seismic contrast between pristine and reworked Archean crust. This contrasts with parts of the northern ECSOOT profile across

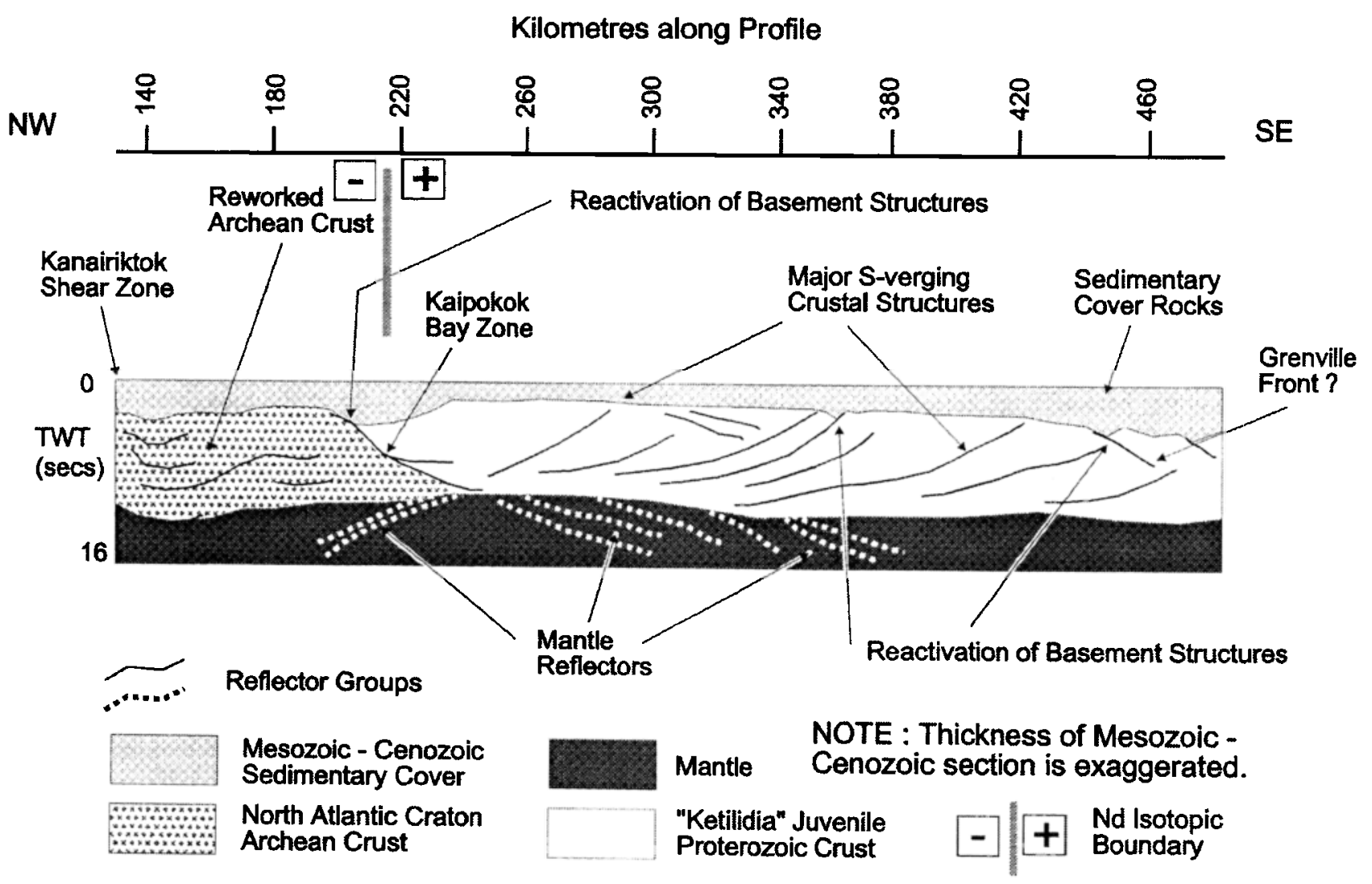

Figure 5. Summary of reflectivity patterns and crustal domains within the Makkovikian - Ketilidian Orogen, as shown in detail by Figure 4 and Plate 1 . Note that there is slight vertical exaggeration to adequately represent the post-Mesozoic sedimentary section. 
the Rae Province, which show pervasive reorientation of reflectors [Hall et al., 1995]. The southeastern portion, from

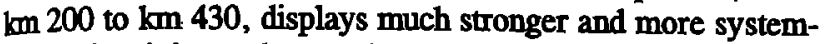
atic reflectivity and crustal-scale structures mostly dipping northwest. This is accompanied by strong, largely subhorizontal reflectivity in the lower crust at $8-10 \mathrm{~s}$ and by consistently dipping reflectivity in the underlying mantle, commonly with an opposing sense.

In conjunction with geological arguments, these two sections of the profile are interpreted to represent crust of contrasting age and origin. The first $200 \mathrm{~km}$ or so represent part of the North Atlantic Craton, but the remainder of the profile is a Proterozoic crustal block, for which the name Ketilidia is used below. The two regions are juxtaposed in the

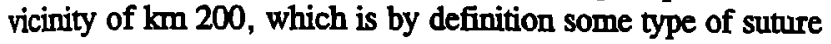
zone.

\subsection{Kaipokok Domain - Border Zone}

There is no doubt that this region comprises reworked Archean crust [Ryan et al., 1983]. However, there is little contrast in reflection character between this region and unreworked Archean crust of the foreland (Figure 4 and Plate 1). The Kanairiktok Shear Zone also has no clear expression on the profile, which suggests that it is not preserved as a major low-angle, dipping structure. The much wider Border Zone in Greenland and the absence of an equivalent structure characterized by a jump in metamorphic facies imply that this shear zone may be a later, discontinuous structure. However, an absence of seismic expression in such poorly reflective Archean crust does not preclude the existence of a major steeply dipping or vertical crustal-scale structure at this point in the profile; there are simply no clear, traceable reflectors to define offsets.

\subsection{Kaipokok Bay Zone - Kobberminebugt Zone}

The narrow, southeast dipping reflector package that ascends to the Mesozoic unconformity (Figure 4b, label G) is probably the offshore extension of the Kaipokok Bay Zone. A simple linear extrapolation from Labrador would suggest a more northerly intersection, but correlation with the Kobberminebugt Zone in Greenland requires an eastward swing of $10^{\circ}-20^{\circ}$ (Figure 2), which would bring the structure to $\mathrm{km}$ 180-190. On land, the Kaipokok Bay and Kobberminebugt Zones mark the southeastern limits of clearly defined surface Archean rocks, and they also have a general correspondence with isotopic contrasts in Proterozoic granites from negative $\epsilon_{\mathrm{Nd}}$ (northwest) to positive $\epsilon_{\mathrm{Nd}}$ (southeast). This isotopic shift is interpreted to mark the southeastern edge of the North Atlantic Craton [Kalsbeek and Taylor, 1985; Kerr and Fryer, 1993; 1994] and occurs some 20-30 km southeast of the Kaipokok Bay Zone. Nd isotopic data from offshore wells confirm that there is a similar contrast in isotopic signatures between $\mathrm{km} 160$ and $\mathrm{km} 200$ adjacent to the profile [Kerr and Wardle, 1997]. This provides further support for interpretation of the $\mathrm{km} 190$ structure as the Kaipokok Bay Zone.

The profiles suggest that the Kaipokok Bay Zone represents a suture, along which Ketilidia has been juxtaposed against the Archean Craton (Figure 5). The eastward displacement of the isotopic boundary relative to surface mylonite zones is explicable if the crustal contributions in the granitoid rocks were derived from relatively deep crustal levels, where Archean basement would predominate. $\mathrm{Pb}$ isotope (galena) data [Wilton, 1991] define an ancient-to-juvenile transition similar to that of Kerr and Fryer [1994] but closer to the Kaipokok Bay Zone. As the galena data likely record shallowlevel hydrothermal systems, they would be more likely to sample the upper (Proterozoic) block. The southeast dip of the km 190 structure and the evidence for northwest directed thrusting and translation in Labrador and Greenland [Allaart, 1976; Ryan et al., 1983] suggest that Ketilidia has been thrust northwestward over the Archean Block at least during the later stages of orogenesis. If the Kaipokok Bay Kobberminebugt Zone correlation is valid, the seismic data also support interpretation of the latter as an important suture zone [cf. Windley, 1991].

\subsection{Aillik Domain - Cape Harrison Domain - Julianehảb Batholith}

At its northwestern end, this section of the profile is bounded by the suggested Kaipokok Bay Zone and at its southeastern end is bounded by a prominent, northwest dipping, structure near $\mathrm{km} 340$ (label P1). The latter corresponds generally with the southern edge of an aeromagnetic high that defines the magmatic belt on both continental shelves (Figure 3a). There is no onland structure in Labrador that can be correlated with this feature, and the Sardloq Zone in Greenland is now considered to lie within the Julianehåb Batholith [Chadwick and Garde, 1996] rather than to separate it from metasedimentary terranes, as previously thought [Windley, 1991]. Nevertheless, it is a potential candidate for the $\mathrm{km} 340$ structure.

The Cape Harrison Domain and Julianehảb Batholith are dominated by syntectonic and posttectonic plutonic rocks, which may have obscured and disrupted the earlier crustal fabrics, and (as they are relatively isotropic) would likely not provide a good seismic response. This may explain the relatively transparent upper crust through much of this region. Isotopic and geochemical studies [Patchett and Bridgwater, 1984; Kalsbeek and Taylor, 1985; Kerr and Fryer, 1993; $1994]$ indicate that many of these granites contain significant amounts of juvenile, probably subcrustal material, indicating that their effects are not restricted to the upper crust. Genetic models [e.g., Kerr and Fryer, 1994] imply that mantlederived, mafic magmas were emplaced (underplated or "intraplated") and interacted themally and chemically with the lower crust. The strongly reflective lower crust between $\mathrm{km}$ 240 and $\mathrm{km} 330$ may owe its origin to such a process. However, there are other possible explanations, such as shearing at the crust-mantle boundary or within the lowermost crust (see later discussion).

\subsection{Psammite and Pelite Zones of Greenland}

This section of the profile shows low-angle, crustal-scale structures that dip gently to the northwest and sole into a highly reflective zone in the lower crust. Much of southernmost Greenland is characterized by high-grade paragneisses displaying flat-lying and low-angle structural trends that have been modified by later folding and intrusion of rapakivi granite massifs [e.g., Bridgwater et al., 1973; Allaart, 1976; 
Chadwick and Garde, 1996]. This pattern has been interpreted in terms of doming and lateral extension associated with granite emplacement [e.g., Bridgwater et al., 1973] or regional thrusting and imbrication of the crust (Windley, 1991). At first sight, the huge northwest dipping structures visible on the seismic profile support the latter concept and are consistent with reports of recumbent isoclinal folds and possible nappe structures in Greenland [Allaart, 1976; Chadwick and Garde, 1996]. The less prominent southeast dipping reflectors in the upper crust (label R, Figure 4 and Plate 1) could also be portions of large-scale, "mushroomlike" nappes; alternatively, they could be earlier structures subsequently disrupted by south verging thrusts, as suggested for the Lithoprobe East on-land profiles in Newfoundland [Quinlan et al., 1992]. However, we cannot rule out an alternative interpretation, that is, that some of this structure is related to postorogenic extensional collapse in this part of the belt [e.g., Hutton et al., 1990].

\subsection{Mantle-Depth Reflectors: Evidence for Plate} Tectonics?

The profile displays at least two sets of reflectors at inferred mantle depths. The most obvious dip southeast beneath Ketilidia from $\mathrm{km} 250$ to $\mathrm{km} 290$ (labels N) and from $\mathrm{km} 300$ to $\mathrm{km} 350$ (label T). There is also a northwest dipping reflective zone from about $\mathrm{km} 220$ to $\mathrm{km} 180$ below the Kaipokok Domain crust (label J). In the northwestern part of the profile, these divergent zones of mantle reflectors meet

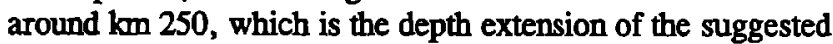
Kaipokok Bay Zone structures and a focal point of asymmetry amongst crustal reflectors. The orientations of crustal and mantle reflectivity are opposed through much of the profile and, southeast of $\mathrm{km} 200$ (beyond the North Atlantic Craton - Ketilidia boundary), appear to be separated by a lower crust - Moho region with strong subhorizontal reflectivity.

Similar, but more focused, mantle-depth reflective zones have been reported from Proterozoic Orogenic belts that are coeval and possibly correlative with the Makkovikian Ketilidian Orogen. The Penokean belt in the Lake Michigan area revealed dipping reflectors descending to $18 \mathrm{~s}$, spatially associated with a zone interpreted as an arc-craton suture. These reflectors were interpreted to represent attempted subduction of Archean crust beneath the arc during collision [Cannon et al., 1991]. A profile across the Svecofennian belt in the Gulf of Bothnia area showed reflectors dipping to $20 \mathrm{~s}$, spatially associated with divergent reflectivity in the crust. The pattern is similar to the Makkovik Province profile at km 250 (Figure 4 and Plate 1), and mantle-depth reflectors were interpreted as a "fossil" subduction zone containing remnant oceanic crust [BABEL Working Group, 1990]. In both cases, mantle reflectors dip north toward the Archean cratons. Mantle reflectors offshore from northern Britain and Ireland have been interpreted as eclogitic slabs representing relict subduction zones [Warner et al., 1996] and may originally have been positioned along strike to the east of the Ketilidian belt, dipping generally toward the south [McBride et al., 1995; Snyder et al., 1996] (Figure 1). Analogous mantledepth reflectors, associated with divergent crustal reflection patterns, have been reported from younger belts such as the Alps [Frei et al., 1989] and the Pyrenees [Choukrone and
ECORS Team, 1989] and also from Archean terranes in Canada [Calvert et al., 1995]. All are interpreted as remnants of subducted oceanic crust or evidence for attempted subduction of continental crust.

Given these recurrent observations from other Precambrian and Phanerozoic Orogens, it seems unlikely that the spatial association of mantle reflectivity with divergent crustal fabrics and a potential suture zone in the Makkovikian - Ketilidian belt is coincidental. These reflectors may indicate the location(s) and polarity(ies) of suture (subduction) zones and have an important bearing on evolutionary models discussed below.

\section{Plate-Tectonic and Geodynamic Models}

\subsection{Plate-Tectonic Models}

Models proposed for the Makkovikian - Ketilidian Orogen may be conveniently divided into "Andean" or "Himalayan" options. Andean models, suggested mostly for southern Greenland [Bridgwater et al., 1973; Chadwick and Garde, 1996], envisage north directed subduction of oceanic crust beneath the North Atlantic Craton, the Julianehåb batholith as a continental magmatic arc, and metasedimentary terranes of southernmost Greenland as a forearc basin (Figure 6a). This subduction polarity was implied also by Ryan [1984] for the Makkovikian Orogen. A variant of this model [Brown et al., 1992] envisaged south directed subduction, with rapakivi-type granites in southernmost Greenland formed in a back arc setting. The Himalayan option was proposed by Windley [1991], who interpreted the Julianehảb Batholith as a magmatic arc sandwiched between the North Atlantic Craton and a southern continental block of unknown heritage. The nature of the crustal substrate to the batholith or the subduction polarity was not explicitly stated, but the latter was implied to be southward. The Psammite and Pelite Zones of southernmost Greenland were interpreted as a back arc basin that later underwent tectonic thickening and postorogenic collapse (Figure 6b). The presumed, but largely undocumented, arc affinity of the Julianehasb Batholith is a crucial element in all three models. Kerr [1989b] proposed a model for the Makkovikian belt with elements of both, suggesting accretion of a composite arc terrane of juvenile affinities through largely south directed subduction, with possible early north directed subduction, suggested by early magmatism in the Kaipokok Domain (Figure $6 c$ ). The abundant plutonic suites of the Cape Harrison Domain were interpreted as late orogenic to postorogenic and (aside from early members) unrelated to subduction of oceanic crust.

\subsection{Relevance of Seismic Reflection Data}

The overall reflectivity pattern of the Makkovikian Ketilidian belt (Figure 5) suggests a 350-km-wide, highly asymmetric, orogenic belt, in which many reflector sets transect the entire crust. The geometry is suggested to be doubly vergent but characterized largely by northwest dipping crustal structures. The general pattern resembles those from the Phanerozoic Appalachian - Caledonian [Quinlan et al., 1992; Hall and Quinlan, 1994; Becumont and Quinlan, 1994] and Pyrenean collisional orogens [Frei et al., 1989; Quinlan et al., 1993; Beaumont and Quinlan, 1994]. It does not 

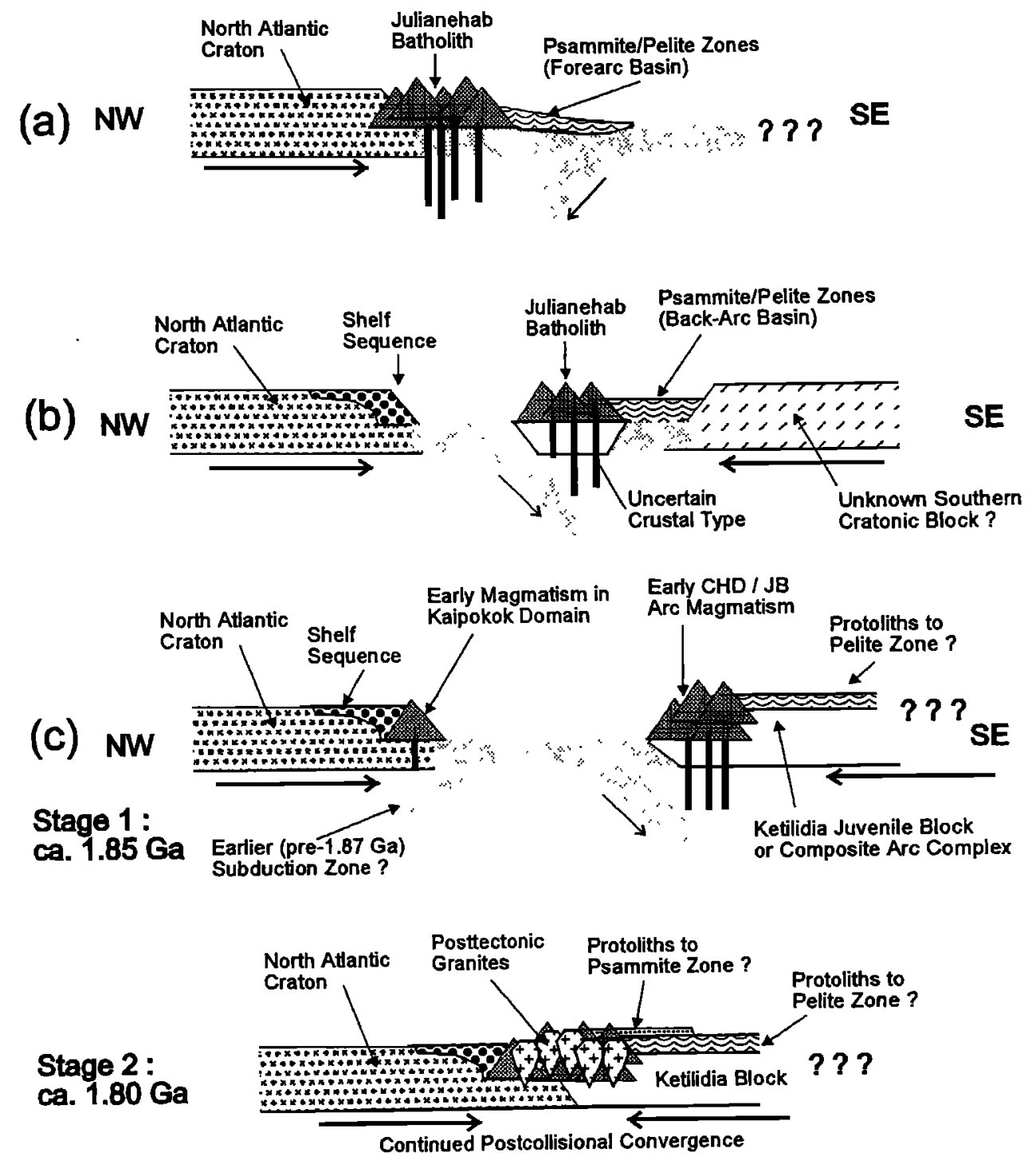

Figure 6. Schematic summary of plate-tectonic models proposed for the Makkovikian - Ketilidian Orogen. (a) Andean option, with subduction to north, and the Julianehăb Batholith, interpreted as a continental margin arc, and the Pelite/Psammite Zones as a forearc basin [after Chadwick and Garde, 1996]. (b) Himalayan option, with subduction to south, Julianeháb Batholith as an arc of unspecified affinity, and pelite/psammite zones as a back arc basin [after Windley, 1991]. (c) Modified collisional model [after Kerr, 1989b]. Initial subduction (pre-1.86 Ga) is northward under the North Atlantic Craton but gives way to southward subduction (stage 1), followed by collision of North Atlantic Craton and Ketilidia (stage 2) and generation of postorogenic granitoid suites. The setting of the Pelite and Psammite Zones is unclear, but they are implied to include sedimentary sequences of different age, for example, early "flysh" and later "molasse" sequences.

obviously resemble patterns from modem subduction accretion zones such as Vancouver Island [Clowes et al., 1987] or New Zealand [e.g., Quinlan et al., 1993]. This empirical similarity suggests that the Makkovikian - Ketilidian Orogen developed its ultimate configuration through either continental or arc-continent collision processes, but it does not rule out the "Andean" analogy at an earlier stage in its development.

Reflective zones at inferred mantle depths dip both northwest and southeast (Figure 5), but the most widespread and persistent mantle reflectivity is southeast dipping, associated with the northwest dipping features in the overlying crust. If the mantle-depth reflectors are related to subduction processes [cf. BABEL Working Group, 1990; Warner et al., 1996], this suggests predominantly southward subduction. However, less extensive northwest dipping mantle-depth reflectors spatially associated with the Kaipokok Bay Zone (Figure 5) raise the possibility also of northward subduction beneath the North Atlantic Craton. Although it is possible that all these mantle features are of the same age, we consider it 
more likely they indicate shifts in subduction polarity over time, which have also been suggested in other Proterozoic orogens [Snyder et al., 1996]. The growing evidence for a complex early tectonic history on the northern margin of the Makkovikian belt [Kerr et al., 1992; Ketchum et al., 1995] implies that convergence may have started as early as $1.9 \mathrm{Ga}$. This complexity emphasizes that models based on a single tectonic configuration are inadequate and that the present architecture of the belt probably developed in two or more stages, as discussed in section 6.6 of the paper.

\subsection{Geological Arguments}

In our view, other types of data argue for predominantly southward subduction, at least in later stages of evolution. Most granitoid rocks of the eastern Makkovik Province and the Julianeháb Batholith were developed in juvenile crust [Kerr and Fryer, 1994; Patchett and Bridgwater, 1984; Kalsbeek and Taylor, 1985; Hamilton et al., 1995], and the crustal suture apparently lies northwest of the main magmatic belt rather than southeast of it. This is the reverse of the expected pattern for a continental arc batholith developed over a north dipping subduction zone. New evidence shows that supracrustal rocks of the Kaipokok Domain must be older than $1.88 \mathrm{Ga}$ [Ketchum et al., 1995], and they are unlikely to represent a back arc setting synchronous with the batholith, as implied by Chadwick and Garde [1996] for their Greenlandic equivalents. Northwest of the Kaipokok Bay Kobberminebugt Zone, the Archean craton contains relatively few Proterozoic calc-alkaline granitoid rocks, and in Labrador these are in part of 1.89- to 1.87-Ga age [Kerr et al., 1992; Ketchum et al., 1995]. These, and possibly the tonalites and trondhjemites of the Island Harbour Bay Intrusive Suite [Ryan et al., 1983; Kerr et al., 1996, must record a different event from the dominant 1.82 - to $1.80-\mathrm{Ga}$ suites of the Cape Harrison Domain - Julianehasb Batholith. Many of these 1.80Ga granites, especially in Labrador, probably postdate subduction, like the voluminous postcollisional suites of Paleozoic belts such as the Appalachian and Hercynian Orogens. The presence of such younger plutonic suites north of the proposed suture has no significance in terms of subduction polarity.

\subsection{Geological Uncertainties}

The spatial and temporal relationships between earlier (arc-like?) and later (postcollisional?) plutonic suites within the Cape Harrison Domain and Julianehăb Batholith remain largely unresolved and impede detailed modeling of these terranes. Relatively young $(1.8 \mathrm{Ga})$ suites with distinctly nonarc signatures are most abundant in Labrador [Kerr et al., 1996], but some older rocks such as the Cape Harrison Metamorphic Suite and 1.84-Ga granodiorites [Kerr et al., 1992] could represent older arc-type suites. Published accounts of the Julianehåb Batholith imply a larger proportion of tonalites and granodiorites than in Labrador, and recent dating suggests older ages of 1.84 to $1.82 \mathrm{Ga}$, with the oldest rocks near the southern margin of the batholith [Hamilton et al., 1995]. There is a need for more dating in both areas and, particularly in Greenland, for systematic geochemical studies to complement any improved geochronological data.
The most enigmatic part of the entire Makkovikian Ketilidian Orogen is southernmost Greenland, represented by the Psammite and Pelite Zones. This region has been interpreted as either a forearc [Chadwick and Garde, 1996] or back arc [Windley, 1991] sedimentary basin, depending on the preferred subduction polarity. The presence of $1.82-\mathrm{Ga}$ granitoid cobbles in a conglomerate and detrital zircon ages ranging from 1.97 to $1.79 \mathrm{Ga}$ [Hamilton et al., 1995, 1996] imply that at least some of the psammites had sources in the Julianehåb Batholith, which could favor either interpretation. The presence of amphibolite and mafic granulite [Allaart, 1976; Chadwick and Garde, 1996] implies contemporaneous mafic magmatism, which is more consistent with a back arc setting, as is the evidence for high geothermal gradients throughout the region [Dempster et al., 1991]. However, both models are difficult to reconcile with growing evidence that at least some of the history of the Psammite and Pelite Zones postdates events recorded by terranes to the northwest. The 1.79-Ga detrital zircons [Hamilton et al., 1996] imply that at least some of the psammites were deposited $20-30 \mathrm{Ga}$ after the formation of most of the Julianehåb Batholith and could therefore also include detritus from younger (postcollisional?) plutonic suites. "Syntectonic" intrusions and concordant garnetiferous granites of probable anatectic origin were formed at 1.79 to $1.78 \mathrm{Ga}$, suggesting that deformation and metamorphism quickly followed sedimentation [Hamilton et al., 1995, 1996] but postdates the 1.82-Ga metamorphism and deformation inferred for the Julianehảb Batholith. Finally, widespread "rapakivi-type" plutonic suites of 1.76- to 1.74-Ga age in southernmost Greenland indicate that this region remained thermally active for a much longer period of time than areas to the north. Thus it seems likely that at least some of the sedimentary protoliths represent a younger (molassetype?) sequence, which underwent subsequent deformation and metamorphism.

It is thus critically important to know if the 1.79-Ga depositional constraint applies to all of the metasedimentary rocks in southern Greenland or if the region includes more than one sedimentary sequence. Geochronological work has naturally emphasized the best preserved conglomeratic and psammitic material, but these may not be fully representative. The evidence that some metasedimentary rocks are intruded by granitoid rocks of the Julianehảb Batholith [Chadwick and Garde, 1996] certainly indicates a wider range of depositional ages. The more pelitic assemblages of southernmost Greenland are a critical part of this puzzle, as these may provide a record of earlier sedimentation or sedimentation linked to an opposing continental margin. The evidence for later, post-1.79-Ga, deformation is difficult to interpret, but coupled with the high geothermal gradients and extensive plutonism of the area, it could be a manifestation of postcollisional collapse and extension [cf. Dewey, 1988].

The available isotopic data from southern Greenland show no evidence of ancient (pre- $2.0 \mathrm{Ga}$ ) continental crust in this region, which argues against continent-continent collision models of the type proposed by Windley [1991], unless the unidentified southern block was of largely juvenile heritage or lay beyond the present confines of the belt. However, although collisional orogens are generally thought of as involving two ancient cratonic blocks, this does not have to be 
the case. For example, the northern Appalachian Orogen records the Ordovician to Silurian collision of Laurentia with Avalonia, a Late Proterozoic block of generally juvenile, arclike affinity which is only some $0.2 \mathrm{Ga}$ older than postorogenic Appalachian granites. In our view, the Appalachian Caledonian and Hercynian Orogens may ultimately provide far more suitable modern analogues for the Makkovikian Ketilidian than either the Himalayan or Andean belts.

\subsection{Relevance to Geodynamic Models of Compressional Orogens}

The Makkovikian - Ketilidian reflectivity pattern (Figure 5) belongs to a growing family of seismic images interpreted as doubly vergent collisional orogens [e.g., Quinlan et al., 1993], although it is more asymmetric than most of these. Computer models have been developed in attempt to understand the origins of this recurrent pattern [Willett et al., 1993; Beaumont and Quinlan, 1994; Beaumont et al., 1994]. The basic model assumes that deformation in the overlying crust is linked to detachment and continued underthrusting of lithospheric mantle originally attached to the downgoing plate (Figure 7). The results vary according to boundary conditions (see later discussion) but commonly produce divergent highstrain zones ("retrowedges" and "prowedges"), which are rooted at the detachment point (Figure 7a). In simple models where no crust is subducted and the detachment point remains fixed, the retrowedge is a narrow, focused zone (i.e., a shear zone), and the prowedge is a more widely distributed thrust belt (Figure 7a).

At face value, the Makkovikian - Ketilidian pattern (Figure 5) resembles this basic configuration (Figure 7a), with the Kaipokok Bay - Kobberminebugt Zone representing the retrowedge and a wider prowedge in southernmost Greenland. However, such an interpretation is inconsistent with the southeast dipping fabric at mantle depths below much of the orogen, which implies subduction in the opposing direction, supported also by geological arguments (see above). The greatest problem in applying geodynamic models of this type is that crustal structures with opposite polarities may be related to very different stages in development, as suggested for divergent reflectivity in the northern Appalachians [Quinlan et al., 1992]. As discussed above, the limited information on timing of deformation in the Makkovikian Ketilidian Orogen now indicates that it is diachronous from north to south.

The thermal structure of the crust influences the type of strain pattern developed in such models, as higher geothermal gradients decrease coupling between crust and mantle or between crustal layers [Beaumont and Quinlan, 1994; Beaumont et al., 1994]. Under such circumstances, deep-level subhorizontal shearing develops via detachment of the crust from the underlying mantle and/or lower crustal detachments, and the width of both prowedges and retrowedges is increased (Figure $7 \mathrm{~b}$ ). The lower crust and Moho region throughout most of the southeastern ("Ketilidia") section of the profile exhibits strong subhorizontal reflectivity, which may indicate the effects of the relatively high geothermal gradients in this region [e.g., Dempster et al., 1991]. This strong subhorizontal reflectivity is largely absent from the North Atlantic Craton section of the profile, where the Moho is very poorly defined (Figure 4 and Plate 1). This suggests that the Archean crust may have responded differently because it was cooler and more strongly attached to its underlying mantle, compared to the juvenile Ketilidia crust, which had been heated and weakened through magmatism.

This final point emphasizes a fundamental shortcoming of geodynamic models of this general type; that is, collisional orogens will almost inevitably involve the interaction of two or more crustal blocks with different properties, because of the thermal and material influence of arc-related magmatism that preceded collision. The modeling of these more complex situations is still in its infancy [e.g., Ellis and Becumont, 1996], but it appears that deformation is largely confined within (and particularly at the edges of) any "weaker" crustal block that is sandwiched between two stronger blocks more firmly attached to their underlying mantle. Because the weaker zone becomes detached from its underlying mantle, it is squeezed and shortened and, with continued convergence, migrates retroward (i.e., in the direction of subduction) relative to the detachment point, as in Figure 7c [e.g., Ellis and Beaumont, 1996]. The point of detachment thus shifts proward relative to the zone of most active deformation to lie beneath or adjacent to the stronger crust on the proside. This retroward motion of the weaker zone is apparently independent of the initial position of the detachment point beneath it and may thus provide an indirect measure of subduction polarity. Such a process during terminal collision may explain the asymmetric reflectivity pattern of the belt and is consistent with the location of most magmatism and deformation south of the crustal suture and south of the focal region where crustal and mantle fabrics diverge (Figure 5). It might also explain the apparently later timing of deformation and metamorphism in the south, which could involve material eroded from the developing orogen. Although this qualitative analogy seems capable of explaining the overall geometry of the reflection pattern, we stress that a multistage model is still required to satisfy all of the geological constraints.

\subsection{Multistage Geodynamic or Plate Tectonic Models}

Although divergent tectonic patterns can be modeled in terms of a single process, as above, many workers prefer multistage models that invoke subduction polarity reversals or late-stage crustal detachments [e.g., Colman-Sadd, 1982; Culotta et al., 1990; Quinlan et al., 1992]. These models are more consistent with the complexity of modern convergent margins and with the geological evidence for temporally discrete deformation events in ancient orogenic belts. The total reflectivity pattern in the Makkovikian - Ketilidian Orogen is difficult to explain by simple one-stage geodynamic models, but a speculative two-stage model, similar to that developed for the Appalachian - Caledonian Belt [Quinlan et al., 1992; Hall and Quinlan, 1994], may be applicable.

It is suggested that convergence began with an early episode of north directed subduction beneath the Archean craton, possibly represented by parts of the Island Harbour Bay Intrusive Suite, $1.89-\mathrm{Ga}$ granites, and early $(1.86 \mathrm{Ga})$ components of the Upper Aillik Group. Northwest dipping mantle-depth reflectors northwest of the $\mathrm{km} 190$ region are interpreted to provide a record of this event. The relationships between these events and supracrustal sequences and early deformation within the Kaipokok Domain and Kaipokok Bay 


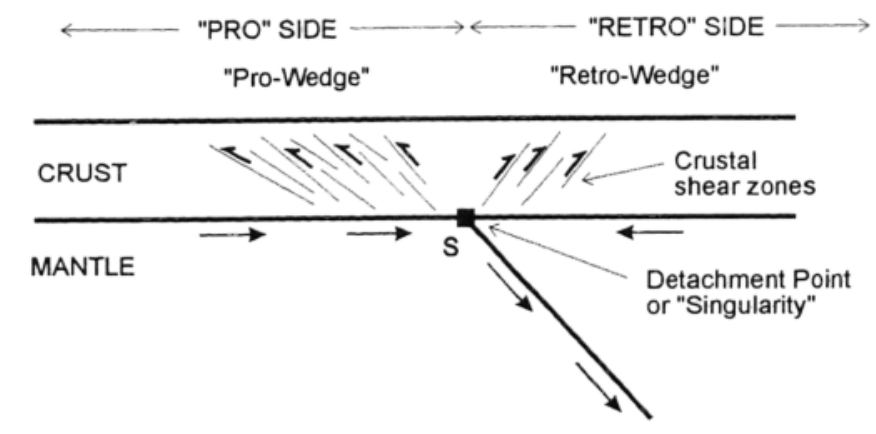

(b)

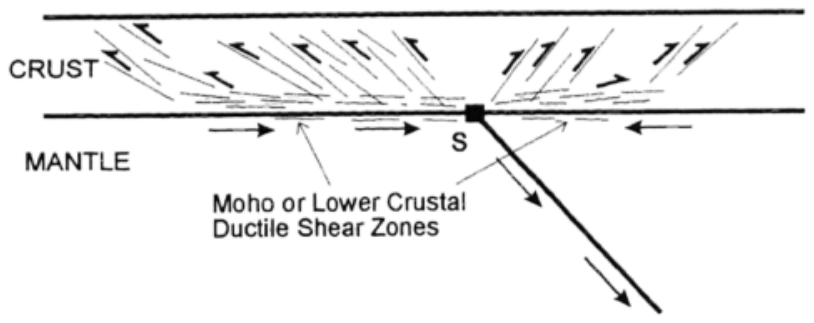

(a)

(c)

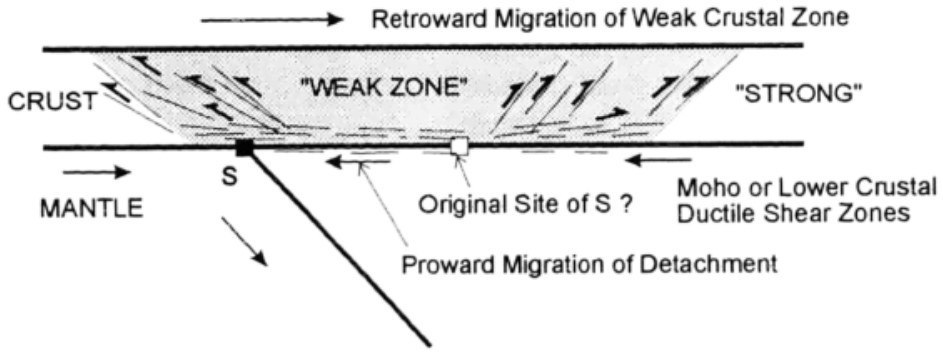

(d)

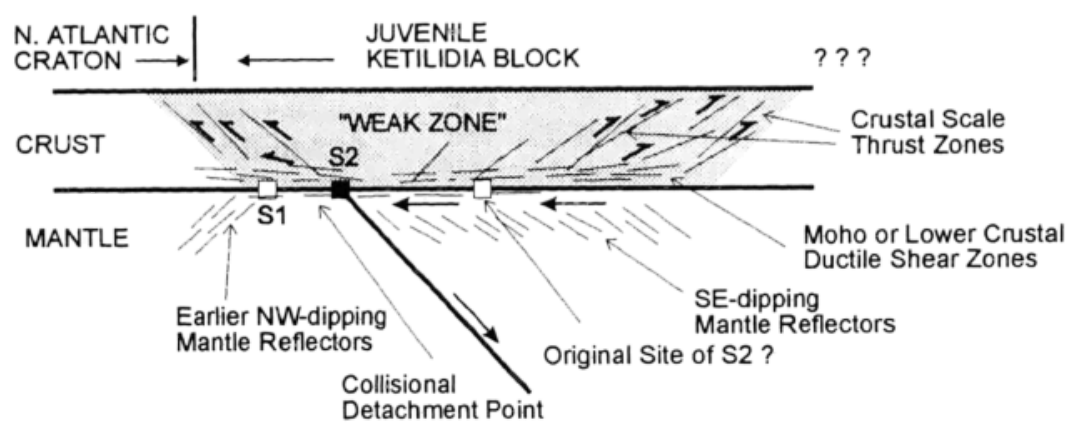

$>$ Sense of vergence $\longrightarrow$ Convengence

Figure 7. (a) Simple geodynamic model for crustal deformation caused by detachment and underthrusting at point $S$ of lithospheric mantle formerly attached to the downgoing plate [after Beaumont et al., 1994]. (b) Variant of above model derived for hotter crust with weaker coupling to underlying lithospheric mantle, showing the widening of deformation zone and development of deep crustal or Moho ductile deformation [after Beaumont et al., 1994]. (c) Variant of model derived for a weaker (hotter) block sandwiched between stronger, cooler crust, showing concentration of deformation at margins of weak block, and retroward migration of weak zone relative to detachment [after Ellis and Beaumont, 1996]. (d) Illustration of reflectivity pattern in Makkovikian - Ketilidian Orogen and its possible interpretation in the light of these models. S1 represents original detachment point of pre-1.85-Ga subduction; S2 is final position of collisional detachment, which may originally have been located farther from S1. Note that all of these diagrams are schematic. 
Zone are presently unclear, as are the reasons for its termination. The preservation of northwest dipping mantle reflectors from this earlier event implies that later convergence involved consumption of oceanic crust that lay between the North Atlantic Craton and Ketilidia by predominantly southward subduction. Ketilidia is envisaged as a (possibly composite) arc terrane, representing juvenile crust of intermediate thickness, and it may be analogous to the Late Precambrian Avalon Block in the Appalachians, which is apparently a collage of arc-type terranes that are only slightly older than the earliest Paleozoic arc terranes of Iapetus. It may have been bounded to the south by an older, but as yet undocumented, cratonic block. It is suggested that parts of the Julianehảb Batholith and some early Makkovik Province granites represent an arc developed on the leading edge of Ketilidia, but the main episode of $1.82-$ to $1.80-\mathrm{Ga}$ magmatism accompanied and postdated terminal oblique collision of Ketilidia and the North Atlantic Craton along the Kaipokok Bay - Kobberminebugt Zone. This event juxtaposed relatively cool, stable Archean crust against thinner, hotter, Proterozoic crust, and these two blocks behaved very differently, as indicated generally by the models of Beaumont et al. [1994] and Ellis and Beaumont [1996]. Following collision, the hotter crust along the leading edge of Ketilidia experienced detachment and shearing at or near the crust-mantle boundary and was squeezed and shortened, leading to southeast verging thrusts and nappes, some of which were rooted in the deep crustal shear zone. It may also have moved southward, relative to the detachment point, which we consider to be now represented by the focal region around $\mathrm{km} 250$ (Figure 5). The preservation of mantle-depth reflectors potentially related to an earlier (northward) subduction implies that the two detachment points (S1 and S2 in Figure 7d) were separated laterally and have been brought together by subduction of intervening mantle lithosphere. The origin of the Psammite and Pelite Zones of southernmost Greenland remains shrouded in uncertainty, as discussed earlier, but they must include at least some material eroded from the developing orogen, which was then quickly affected by continued deformation and metamorphism. However, they could also include older components representing an earlier back arc environment or a sedimentary prism developed adjacent to an outboard cratonic block. The data are presently inadequate to explore these alternatives further. Finally, some of the later deformational history in the southern part of the belt and, by inference, some of the structures imaged by the seismic profile may have developed or have been accentuated during postcollisional extensional collapse of the orogen rather than through continued convergence. Many of the features of southernmost Greenland (e.g., high geothermal gradients and posttectonic magmatism) correspond to those outlined by Dewey [1988] for such zones, as noted also by Windley [1991]. Our model has some similarities to the proposals of Windley [1991] but implies a "subduction flip" of the opposite sense to that proposed by Snyder et al. [1996] as part of a generalized arc-continent collision model for Proterozoic orogenic belts. However, we stress that our proposal in no way implies that the latter is incorrect but instead emphasizes that the development of various belts and lateral segments of the same belt can be complex and varied. In the case of the Makkovikian - Ketilidian Orogen, the reflection fabrics related to the earlier event were preserved, whereas they were eradicated elsewhere because subduction polarity reversals postdated, rather than predated, arc accretion and because the younger subduction zone "crossed" the older relict zone [Snyder et al., 1996].

Although speculative, our model is consistent with many features of the belt and the seismic reflection profiles and provides a starting point for more sophisticated analyses. Although we believe the basic premises of simple geodynamic models [e.g., Beaumont et al., 1994] to be correct, we stress that such analyses must ultimately incorporate the superposition of crustal fabrics related to temporally discrete events, the juxtaposition of crustal blocks that have differing thermal and/or compositional properties, and the effects of oblique convergence. All of these factors represent "general cases" in orogenic development and will govern the response of an orogenic system to continued convergence following collisional or accretionary events.

Acknowledgments. This paper represents Lithoprobe contribution 998, and seismic reflection work forms part of the Canadian Lithoprobe project, supported by the National Sciences and Engineering Research Council of Canada (NSERC) and the Geological Survey of Canada. Geological field work in Labrador relevant to this paper was largely supported by cost-shared agreements between the govermments of Canada and Newfoundland-Labrador. Reviewers James Knapp and Steve Lucas are thanked for pointing out shortcomings and suggesting improvements to the original manuscript.

\section{References}

Allaar, J. H., Ketilidian mobile belt of West Greenland, in Geology of Greenland, edited by A. Escher and W.S. Watt, pp. 120-150, Grenlands Geol. Unders., Copenhagen, 1976.

BABEL Working Group, Evidence for Early Proterozoic plate tectonics from seismic reflection profiles in the Baltic Shield, Nature, 348, 34-38, 1990.

Beaumont, C., and G. Quinlan, A geodynamic framework for interpreting crustal scale seismic reflectivity patterns, Geophys. J. Int., 116, 754783, 1994.

Beaumont, C., P. Fullsack, and J. Hamilton, Styles of crustal deformation in compressional orogens caused by subduction of the underlying lithosphere, Tectonophysics. 232, 119-132, 1994.
Berthelsen, A., and N. Henriksen, Geological map of Greenland (descriptive text), Rep. 186, Ivigut sheet, 1:100,000 scale, 169 pp., Gronlands Geol. Unders., Copenhagen, 1975.

Bridgwater, D., and L. Schiøtte, The Archean gneiss complex of northern Labrador: A review of current results, ideas and problems, Bull. Geol. Soc. Den., 39, 153-166, 1991.

Bridgwater, D., A. Escher, and J. Watterson, Tectonic displacments and thermal activity in two contrasting Proterozoic mobile belts from Greenland, Philos. Trans. R. Soc. London, Ser. A, 273, 513-533, 1973.

Brown, P. E., T. J. Dempster, T. N. Harrison, and D. $H$. Hutwon, The rapakivi granites of south Greenland - crustal melting in response to exten- sional tectonics and magmatic under-plating. Trans. R. Soc. Edinburgh Earth Sci., 83, 173-178, 1992.

Bullard, E. C., J. E. Everett, and A. G. Smith, The fit of the continents around the Atlantic, Philos. Trans. R. Soc., Ser. A 258, 41-51, 1965.

Calvert, A. J., E. W. Sawer, W. J. Davis, and J. N. Ludden, Archaean subduction inferred from seismic images of a mantle suture in the Superior Province, Nature, 375, 670-674, 1995.

Cannon, W. F., M. W. Lee, W. J. Hinze, K. J. Schulz, and A. G. Green. Deep crustal structure of the Precambrian basement beneath northern Lake Michigan, midcontinent North America, Geology, 19, 207-210, 1991.

Chadwick, B., and A. A. Garde, Paleoproterozoic 
oblique convergence in south Greenland: A reappraisal of the Ketilidian Orogen, in Crustal Evolution in the North Atlantic Region, edited by T.S. Brewer and B.P. Atkin, Spec. Pap. Geol. Soc. Am., 112, 179-197, 1996.

Chadwick, B., P. Erfur, T. Frisch, R. A. Frith, A. A. Garde, H. K. Schonwandt, H. Stendal, and B. Thomassen, Re-interpretation of aspects of Ketilidian geology, Rep. 163, 31 pp., Gronlands Geol. Unders., Copenhagen, 1994.

Chian, D., and J. Louden, The strucuure of Archean - Ketilidian crust along the continental shelf of southwest Greenland from a seismic refraction profile, Can J. Earth Sci, 29, 301-313, 1992.

Choukrone, P., and ECORS Team, The ECORS Pyrenean deep seismic reflection profile data and the overall structure of an orogenic belt, Tectonics, 8, 23-39, 1989.

Clowes, R. M., M. T. Brandon, A. G. Green, C. J. Yorath, A. Sutherland-Brown, E. R. Kanasewich, and C. Spencer, LITHOPROBE southern Vancouver Island: Cenozoic subduction complex imaged by deep seismic reflections, Can. J. Earth Sci., 24, 31-51, 1987.

Colman-Sadd, S. P., Two-stage continental collision and plate driving forces, Tectonophysics, 90, 263-282, 1982.

Culotta, R. C., T. Pratt, and J. Olivier, A tale of two sutures: COCORP's deep seismic surveys of the Grenville Province in the eastern U.S. midcontinent, Geology. 18, 646-649, 1990.

Culshaw, N. G., and J. W. F. Ketchum, The Kaipokok Zone of the Makkovik Orogen - An early Proterozoic terrane boundary?, Rep. 45, pp. 7-22, Lithoprobe Secr., University of British Columbia, Vancouver, B.C., 1994.

Dempster, P. J., T. N. Harrison, P. E. Brown, and D. H. Hutton, Low-pressure granulites from the Ketilidian Mobile Belt of south Greenland, $J$. Petrol., 32, 979-1004, 1991.

Dewey, J. F., Extensional collapse of orogens, Tectonics, 7, 1123-1139, 1988.

Ellis, S., and C. Beaumont, Models of convergent boundary tectonics: implications for the interpretation of Lithoprobe data, Rep. 57, pp. 59-109, Lithoprobe Secr., University of British Columbia, Vancouver, B.C., 1996.

Emslie, R. F., Anorthosite massifs, rapakivi granites and Late Proterozoic rifting of North America, Precambrian Res., 7, 61-98, 1978.

Ermanovics, I. F., Geology of Hopedale Block. southern Nain Province, and the adjacent Proterozoic terranes, Labrador, Newfoundland, Mem., Geol. Surv. Can, 431, 161 pp, 1992.

Frei, W., P. Heitzmann, P. Lehner, S. Muller, R. Olivier, A. Pfifner, A. Steck, and P. Valasek. Geotraverses across the Swiss Alps, Nature, 340, 544-548, 1989.

Gower, C. F., and A. B. Ryan, Proterozoic evolution of the Grenville Province and adjacent Makkovik Province in east-central Labrador, in The Grenville Province, edited by J.M. Moore, A.J. Baer, and A. Davidson, Spec. Pop. Geol. Assoc. Can., 31, 281-295, 1986.

Gower, C. F., and A. B. Ryan, Two stage felsic volcanism in the Lower Proterozoic Upper Aillik Group, Labrador, Canada: Its relationship to syn- and post-kinematic plutonism, in Geochemiszy and mineralization of Proserozoic Volcanic Suites, edited by T.C. Pharoh et al., Geol. Soc. Spec. Publ., 33, 201-210, 1987.

Gower, C. F., A. B. Ryan, and T. Rivers, Mid-Proterozoic Laurentia-Baltica: An overview of its evolution and a summary of the contributions made by this volume, in Mid-Proterozoic Laurentia - Baltica, edited by C.F. Gower, A.B. Ryan, and T. Rivers, Spec. Pap. Geol. Assoc. Can., 38, 1-23, 1990

Gower, C. F., J. Hall, G. J. Kilfoil, G. M. Quinlan, and R. J. Wardle, Roots of the Labradorian orogen in the Grenville Province in southeast Labrador: evidence from marine, deep-seismic reflection date, Tectonics, 16, 795$809,1997$.

Gulson, B. L., and T. E. Krogh, Evidence of multiple intrusion, possible resetting of U-Pb ages, and new crystallization of zircons in the post-tectonic intrusions (Rapakivi Granites) and gneisses from S. Greenland, Geochim. Cosmochim. Acta, 39, 65-82, 1975.

Hall, J., and G. Quinlan, A collisional crustal fabric recognized from seismic reflection profiles of the Appalachian - Caledonide Orogen, Tectonophysics, 232, 31-42, 1994.

Hall, J., R. J. Wardle, C. F. Gower, A. Kerr, K Coflin, C. E. Keen, and P. Carroll, Proterozoic orogens of the northeastern Canadian Shield: New information from crustal reflection seismic surveys, Can. J. Earth Sci., 32, 1119-1131, 1995.

Hamilton, M. A., A. A. Garde, B. Chadwick, and C. Swazer, Ketilidian Orogen, south Greenland: Paleoproterozoic are accrecion, sedimentation and metrmorphism recorded by U-Pb geochronology, paper presented at International Conference on Tectonics and Metallogeny of Early/Mid Precambrian Orogenic Belts, University of Quebec, Montreal, Quebec, Canada. August 1995.

Hamilton, M. A., A. A. Garde, B. Chadwick, and C. Swager, Observations on paleoproterozoic fore-arc sedimentation and deformation: Preliminary $\mathrm{U}-\mathrm{Pb}$ results from the Ketilidian Orogen, south Greenland, Rep. 57, pp. 112-123, Lithoprobe Secr., University of British Columbia, Vancouver, B.C., 1996.

Hutton, D. H., T. J. Dempster, P. E. Brown, and $S$. M. Becker, A new mechanism of granite emplacement: Rapakivi intrusions in active extensional shear zones, Nature, 343, 452-454, 1990.

Kalsbeek, F., and P. N. Taylor, Isotopic and chemical variation in granites across a Proterozoic continental margin - The Ketilidian mobile belt of South Greenland, Earth Planet. Sci. Lett. 73, 65-80, 1985.

Kalsbeek, F., L. M. Larsen, and J. Bondam, Geological map of Greenland, (descriptive text), Sydgrenland, sheet 1, 1: 500,000 scale, Gronlands Geol. Unders., Copenhagen, 1990.

Keen, C. E., P. Potter, and S. P. Srivastava, Deep seismic reflection data across the conjugate margins of the Labrador Sea. Can. J. Eanh Sci., 31, 192-205, 1994.

Kerr, A., Geochemistry of the Trans-Labrador Granitoid Belt, Canada: A quantitarive comparative study of a Proterozoic Batholith and possible Phanerozoic counterparts, Precambrian Res., 45, 1-17, 1989a.

Kerr, A., Early Proterozoic granitoid magmatism and crustal evolution in the Makkovik Province of Labrador: A geochemical and isotopic suidy, Ph.D. thesis, 528 pp., Mem. Univ. of Newfoundland, St. John's, Newfoundland, Canada, $1989 \mathrm{~b}$.

Kerr, A., and B. J. Fryer, Nd isotopic evidence for crust-mande interaction in the genesis of A-type granitoid suites in Labrador, Canada, Chem. Geol, 103, 39-60, 1993.

Kerr, A., and B. J. Fryer, The importance of lateand postorogenic crustal growth in the Early Proterozoic: Evidence from Sm-Nd studies of igneous rocks in the Makkovik Province, Canada, Earth Planet. Sci. Lett., 125, 71-88, 1994.

Kerr, A., and R. J. Wardle, Definition of an Archean - Proterozoic crustal sunure by isotopic studies of basement intersections from offshore wells in the southern Labrador Sea, Can. J. Earth Sci., 34, 209-214, 1997.

Kerr, A. , T. E. Krogh, F. Corfu, U. Schårer, S. S. Gandhi, and Y. Y. Kwok, Episodic Early Proterozoic granitoid plutonism in the Malkovik
Province, Labrador: U-Pb geochronological dat and geological implications, Can. J. Earth Sci., 29, 1166-1179, 1992.

Kerr, A., B. Ryan, C. F. Gower, and R. J. Wardle, The Makkovik Province: Extension of the Ketilidian Mobile Belt into mainland North America, in Crustal Evolution in the North Atlantic Region, edited by T.S. Brewer and B P. Atkin, Spec. Pap. Geol. Soc. Am., 112, 155-179, 1996.

Ketchum, J. W. F., N. G. Culshaw, and G. R. Dunning, Tectonic history and $\mathrm{U}-\mathrm{Pb}$ geochronology of the Early Proterozoic Makkovik Ketilidian Orogen near Kaipokok Bay, Labrador: Preliminary results, paper presented at International Conference on Tectonics and Metallogeny of Early/Mid Precambrian Orogenic Belts, University of Quebec, Montreal, Quebec, Canada, August 1995.

Kranck, E. N., The rock-ground of the coast of Labrador and the connection between the Pre-Cambrian of Greenland and north America, Bull. Comm. Geol. Finl., 125, 39-65, 1939.

Louden, K. E., and Fan, J., Crustal structures of Grenville Makkovik and southern Nain provinces along the Lithoprobe ECSOOT transect: Preliminary results of seismic refraction and gravity models and their tectonic implications, Can. J. Earth Sci., in press, 1997.

Loveridge, W. D., I. F. Ermanovics, and R. W. Sullivan, U-Pb ages on zircon from the Maggo Gneiss, the Kanairiktok Plutonic Suite and the Island Harbour Plutonic Suite, coast of Labrador, Newfoundland, in Radiogenic Age and Isolopic Studies: Repon 1, Geol. Surv. Can. Pap. 87-2, 59-65, 1987.

McBride, J. H., D. B. Snyder, M. P. Tate, R. W. England, and R. W. Hobbs, Upper mantle reflector structure and origin beneath the Scottish Caledonides, Tectonics, 14, 1351-1367, 1995.

Patchetr, P. J., and D. Bridgwater, Origin of continental crust of 1.9-1.7 Ga age defined by $\mathrm{Nd}$ isotopes in the Ketilidian terrain of South Greenland, Contrib. Mineral. Petrol., 87, 311-318, 1984.

Quinlan, G. M., J. Hall, H. Williams, J. Wright, S. Colman-Sadd, S. J. O'Brien, G. Stockmal, and F. Marillier, Onshore seismic reflection transects across the Newfoundland Appalachians, Can. J. Earth Sci., 29, 1865-1877, 1992.

Quinlan, G. M., C. Beaumont, and J. Hall, Tectonic model for crustal seismic reflectivity patterns in compressional orogens, Geology, 21. 663-666, 1993.

Reid, I., Crustal structure across the Nain Makkovik boundary on the continental shelf off Labrador from seismic refraction data, Can. $J$. Earth Sci., 33, 460-471, 1996.

Roest, W. R., and S. P. Srivastava, Sea-floor spreading in the Labrador Sea: A new reconstruction. Geology, 17, 1000-1003, 1989.

Ryan, A. B. Regional geology of the central part of the Central Mineral belt, Labrador, Mem. 3 , 185 pp., Miner. Dev. Div., Newfoundland Dep. of Mines and Energy, St. John's, NF, 1984.

Ryan, A. B., A. Kay, and I. Ermanovics, The geology of the Makkovik Subprovince between Kaipokok Bay and Bay of Islands, Labrador, Map 83-38 and 83-41, 21 pp. (with descriptive notes), Miner. Dev. Div., Newfoundland Dep. of Mines and Energy, St. John's, NF, 1983.

Schărer, U., T. E. Krogh, R. J. Wardle, A. B. Ryan, and S. S. Gandhi, U-Pb ages of Early and Middle Proterozoic volcanism and metamorphiem in the Makkovil Orogen, Labrador, Can. J. Eanth Sci., 25, 1098-1107, 1988.

Snyder, D. B., S. B. Lucas, and J. H. McBride, Crustal and mantle reflectors from Palcoproterozoic orogens and their relation to 
arc-continent collisions, in Crustal Evolution in the North Arlantic Region, edited by T.S. Brewer and B.P. Akin, Spec. Pap. Geol. Soc. Am., 112, 1-25, 1996.

Srivastava, S. P., and W. R. Roest, Seafloor spreading history, in East Coast Basin Atlas: Labrador Sea, edited by J.S. Bell, All. Geosci. Cent., Geol. Surv. Can., Ottawa, ON, 1989.

Srivastava, S. P., and J. Verhoef, Evolution of Mesozoic sedimentary basins around the north central Atlantic: A preliminary plate kinematic solution, in Basins on the Atlantic Seaboard: Petrolewm Geology. Sedimentology and Basin Evolution, edited by J. Pamell, Geol. Soc. Spec. Publ., 62, 397-420, 1992.

Sutton, J. S. B. E. Marten, A. M. S. Clark, and I. Knight, Correlation of Precambrian supracrustal rocks of coastal Labrador and southwestern Greenland, Nature, 238, 122-123, 1972

van Breeman, O., M. Aftalion, and J. H. Allaar, Isocopic and geochronologic studies on granites from the Ketilidian mobile belt of South Greenland, Geol. Soc. Am. Bull., 85, 403-412, 1974.

Wardle, R. J., C. F. Gower, and A. Kerr, The southeastern margin of Laurentia ca. 1. $7 \mathrm{Ga}$ :
The case of the missing crust, paper presented at Anmual Meeting of the Geological Association of Canada-Mineralogical Association of Canada, Vancouver, Br. Columbia, Canada, 1990.

Wardle, R. J., and D. G. Bailey, Early Proterozoic sequences in Labrador, in Proterozoic Basins of Canada, edited by F.H.A. Campbell, Spec. Pap. Geol. Surv. Can., 81-10, pp. 331-359, 1981.

Warner, M., J. Morgan, P. Barton, P. Morgan, C. Price, and K. Jones, Seismic reflections from the mantle represent relict subduction zones within the continental lithosphere, Geology, 24, 39-42, 1996.

Wasteneys, H., R. J. Wardle, and T. E. Krogh, Extrapolation of tectonic boundaries across the Labrador Shelf: U-Pb geochronology of well samples, Rep. 32, pp. 145-174, Lithoprobe Secr., University of British Columbia, Vancouver, B.C., 1992.

Willetr S., C. Beaumont, and P. Fullsack, Mechanical model for the tectonics of doubly-vergent compressional orogens, Geology, 21, 371-374, 1993.

Wilton, D. H. C., Metallogenic and tectonic impli- cations of $\mathbf{P b}$ isotope data for galena separates from the Labrador Central Mineral Belt, Econ. Geol., 86, 1721-1736, 1991.

Windley, B. F., Early Proterozoic collision tectonics, and rapakivi granites as intrusions in an extensional thrust-thickened crust: The Ketilidian Orogen, south Greenland, Tectonophysics, 195, 1-10, 1991.

C.F. Gower, A. Kerr, B. Ryan, and R.J. Wardle, Geological Survey of Newfoundland and Labrador, Department of Mines and Energy, P.O. Box 8700, St. John's, Newfoundland, Canada A1B 4J6. (e-mail: akr@zeppo.geosurv.gov.nf.ca; cfg@ zeppo.geosurv.gov.nf.ca; abr@zeppo.geosurv.gov. nf.ca; rjw@zeppo.geosurv.gov.nf.ca)

J. Hall, Deparment of Earth Sciences, Mernorial University of Newfoundland, St. John's, Newfoundland, Canada A1B 3X5. (e-mail: jhall@ tomig.esd.mun.ca)

(Received March 27, 1996;

revised March 13, 1997;

accepted July 21,1997 .) 